\title{
A Creeping Intracontinental Thrust Fault: Past and \\ 2 Present Slip-Rates on the Northern Edge of the Tien
}

\section{shan, Kazakhstan}

4 D. Mackenzie ${ }^{1,9}$, Richard Walker ${ }^{1 \star}$, Kanatbek Abdrakhmatov ${ }^{2}$,

${ }_{5}$ Grace Campbell $^{3,4}$, Andrew Carr ${ }^{5}$, Christoph Gruetzner ${ }^{3,6}$,

6 Aidyn Mukambayev ${ }^{7}$ Magali Rizza ${ }^{8}$

1 COMET, Dept. of Earth Sciences, University of Oxford, Oxford, OX1 3AN, UK.

2 Institute of Seismology, National Academy of Sciences, Kyrgyz Republic.

3 COMET, Bullard Laboratories, Cambridge University, Madingley Road, Cambridge, CBЗ OEZ, UK.

4 Now at Arup, 13 Fitzroy St, London, Middlesex W1T 4BQ, UK.

5 School of Geography, Geology and the Environment, University of Leicester, University Road, Leicester LE1 $7 R H, U K$.

6 Now at Friedrich-Schiller-Universität Jena, Institut für Geowissenschaften,

Burgweg 11, 07749 Jena, Germany.

7 Data Center of the Institute of Geophysical Researches, L. Chaikinoy Street 4, Almaty 050020, Kazakhstan.

8 Aix Marseille Univ, CNRS, IRD, INRA, Coll France, CEREGE, Aix-en-Provence, France

9 Now at 3vGeomatics, Vancouver, BC, V5Y 1K6, Canada 


\section{SUMMARY}

We demonstrate that a continental interior reverse fault is deforming by aseismic creep, presently, and likely also in the long term. The Karkara Rangefront Fault, part of the larger Main Terskey Front, forms the northern boundary of the high Terskey Tien Shan in southeastern Kazakhstan and is a mature structure with evidence for high slip rates throughout the late Cenozoic. Combining field studies with a satellite stereo-image derived digital elevation model (2 m resolution), we map a series of fluvial terraces along the rangefront which are uplifted by up to $\sim 300 \mathrm{~m}$ above the present river level. Radiocarbon ages from one catchment constrain the ages of the lowermost two terraces to be $\sim 4-5 \mathrm{ka}$ and $\sim 10-15 \mathrm{ka}$, consistent with prominent, regionally extensive terraces observed elsewhere in the Tien Shan. Based on conservative estimates for the fault dip under the displaced terraces, we estimate a slip rate along the fault plane of $3.5_{-0.4}^{+1.7} \mathrm{~mm} / \mathrm{yr}$ on the Karkara Rangefront Fault and a further $>0.8 \mathrm{~mm} / \mathrm{yr}$ on a fold structure in the Kegen basin that we infer is driven by a detachment from the main rangefront. We therefore estimate a minimum shortening rate across the rangefront of $1.1-3.3 \mathrm{~mm} / \mathrm{yr}$. Elastic modelling of the regional GPS velocity field suggests that the fault is presently creeping at $\sim 3 \mathrm{~mm} / \mathrm{yr}$ (horizontal shortening), consistent with the upper limit of our Late Quaternary slip rate estimate. This is the fastest known slip rate in the northern Tien Shan and the only individual structure resolved in the regional velocity field. At present the fault is accumulating minimal strain, and there is evidence in the geomorphology that this creep is sustained in the long term, but whether or not it is also capable of generating earthquakes requires further study.

Key words: Seismic Cycle - Continental tectonics: compressional - Crustal structure - Geomorphology - Aseismic Creep

* Correspondence to: richard.walker@earth.ox.ac.uk 


\section{INTRODUCTION}

${ }_{34}$ The classical model of earthquakes and faulting in the continents is that of stick-slip be-

35 haviour on discrete faults. This model is characterised by three main parts: interseismic strain

${ }_{36}$ accumulation, coseismic release and postseismic relaxation (e.g. Reid 1910; Smith \& Wyss

${ }_{37}$ 1968; Thatcher 1983). More recently however, a subset of faults, generally major continental

${ }_{38}$ strike-slip faults, have been observed to deform by a different mode - that of aseismic creep,

39 either at steady rates or in shorter bursts, which accommodates some fraction of the long-

${ }_{40}$ term fault motion. The interactions between creeping and non-creeping segments of faults

${ }_{41}$ and the mechanisms by which they creep are the subject of much discussion (e.g. Avouac

${ }_{42}$ 2015; Harris 2017) and the seismic hazard that creeping faults pose is not well understood

${ }_{43}$ (Chen \& Bürgmann 2017). Case studies of creeping continental faults have generally been

${ }_{44}$ conducted on large strike-slip faults at or near plate margins. By comparison fault slip rates

${ }_{45}$ in the more slowly deforming continental interiors are often too low and instrumentation

${ }_{46}$ too sparse to resolve creep.

${ }_{47}$ Here, we present a case study of the northern rangefront fault of the high Tien Shan,

${ }_{48}$ adjacent to the highest peaks of the range, where creep on a continental interior thrust fault is

${ }_{49}$ suspected (Figure1). The regional GPS velocity field shows that the Tien Shan accommodate

50 $\sim 20 \pm 2 \mathrm{~mm} / \mathrm{yr}$ of shortening (at the longitude of this study), amounting to around half the

${ }_{51}$ total India-Eurasia plate convergence (Tapponnier \& Molnar 1979; Abdrakhmatov et al.

52 1996; Zubovich et al. 2010). Approximately half of this shortening, $\sim 10 \mathrm{~mm} / \mathrm{yr}$, is taken

${ }_{53}$ up across the northern and central Tien Shan, with the other half accommodated along the

${ }_{54}$ northern margin of the Tarim Basin. The majority of faults are not resolved in the regional

${ }_{55}$ GPS velocity field, which shows a remarkably linear velocity ramp right across the Tien

${ }_{56}$ Shan (England \& Molnar 2015). The only exception is a discrete step in the velocity field,

${ }_{57}$ extending from Song-Kul lake in Kyrgyzstan at least as far as the Kegen Basin, roughly

${ }_{58}$ paralleling the Terskey Range (Figure 1). The velocity field of Zubovich et al. (2010) only

${ }_{59}$ extends as far as the Kazakh-Chinese border, so it is possible that the step extends eastwards

${ }_{60}$ into China but is unresolved. England \& Molnar (2015) suggest that this step is probably 
${ }_{84}$ provided in the main text as tables.

\section{${ }_{85} 2$ QUATERNARY SLIP ON THE KARKARA RANGEFRONT}

${ }_{86}$ The KRF strikes approximately E-W and dips to the south, forming the southern boundary ${ }_{87}$ of the Kegen Basin (Figure 11). At the western end, the fault splits into several strands, one 
88

following a fold structure to the edge of lake Issyk Kul (and likely underneath, Gebhardt et al. 2017), while the other follows the main rangefront of the high topography south of the lake (MTF, Figure 1 b). The hangingwall range is cored with Palaeozoic basement, but the surface expression of the KRF has propagated 2-3 km north from the Palaeozoic contact, and Neogene basin deposits are uplifted in the immediate hangingwall. We measure the present day shape of the terraces to estimate the underlying fault structure and the uplift and hence fault slip since abandonment (e.g. Thompson et al. 2002; Burbank \& Anderson 2011).

The river terraces are cut into Neogene sediments and generally capped with fluvial gravels, followed by a post-abandonment soil development. Unfortunately, the Neogene deposits are poorly exposed and heavily eroded so we were unable to estimate bedding plane orientations in any of the river catchments. At three river valleys crossing the fault, we map prominent flights of terraces (catchments Rc1-3, Figures 1b, 2b). At the eastern end (Rc1), the fault trace reaches the surface $\sim 2 \mathrm{~km}$ from the Palaeozoic-Cenozoic contact, but the contact strikes SW while the fault continues E-W, giving a separation of $\sim 15 \mathrm{~km}$ at catchment Rc3, suggesting lateral changes in segmentation or in the shallow fault geometry (Figure 2).

At Rc1 we used the field observations, SfM and satellite DEMs to map the fluvial terraces at high resolution. We then extended the terrace mapping along the rangefront to using the satellite derived DEM to cover a much larger area than is practical in the field. Several additional catchments Rc4-6 are also covered by the DEM, but they are much smaller than Rc1-3 so the terraces are shorter and fewer are preserved. Mapping and terrace profiles for Rc4-6 are given in Supplement S2. In all six catchments we identify at least three well defined terraces, one of which is uplifted by $\sim 15-20 \mathrm{~m}$ in each case and shows similar degrees of post-abandonment incision - we suggest that this surface may correspond to the widespread Q(3)III surface identified by Thompson et al. (2002). 


\subsection{Results: River Catchment 1 (Rc1), High resolution survey}

115 At the eastern end of the Karkara fault section, we chose a river valley site with a well

developed flight of terraces (Figure $3 \mathrm{a}-\mathrm{c}$ ) as the case study for high-resolution surveying with SfM (Figure 3d). In its upper catchment, the river runs $\mathrm{S}$ to $\mathrm{N}$ in a deeply incised valley in the Palaeozoic bedrock, before crossing into Cenozoic deposits $\sim 2 \mathrm{~km}$ from the main fault trace. Where exposed, the Neogene sediments are homogeneous fine grained, dark red in colour, with a clay-like consistency and show little stratigraphy. The poorly consolidated material and generally only thin gravel cap on the terraces, has not preserved fault plane exposures. Landsliding has also occurred in the sediments in several locations along the rangefront (Figure 3b,c), obscuring the terrace levels.

\subsubsection{Rc1: Terrace offsets}

Using the combined elevation datasets, we map four discrete major terrace levels at Rc1 (T1-4), of which three are preserved on both sides of the river (Figure 3b-d). A kinematic GPS profile along the river base was used to constrain the present-day longitudinal river profile as this provides a better constraint on the river elevation than the photogrammetry DEMs, which decorrelate on water. We determine the elevations of each terrace above the current footwall surface and the river level. Figure 4 shows profiles of each terrace with a constant river gradient removed (estimated from the approximately linear stretch of the river profile $<1600 \mathrm{~m}$ upstream from the fault).

The most recent major terrace (labelled T1) is observed as a pair of well preserved surfaces on both sides of the present river channel, though only the western side is preserved at the fault trace. The surface is generally planar and parallel to the river bed, with the exception of two sections, $\sim 100-220 \mathrm{~m}$ and $\sim 750-900 \mathrm{~m}$ from the fault surface trace (Figure 4), which have been tilted to the south, and which we attribute to step changes in fault dip below these regions (e.g. Le Béon et al. 2014). We measure the displacement of the T1 surface since abandonment relative to the downthrown fan surface as $12.9 \pm 0.5 \mathrm{~m}$ in the 
immediate $50-100 \mathrm{~m}$ of the hangingwall, reducing to $10.0 \pm 0.5 \mathrm{~m} \sim 200 \mathrm{~m}$ from the scarp (Figure 4).

The second terrace (labelled T2, Figures 3 ) is also preserved on both sides of the river, though only a small remnant exists on the eastern side around $\sim 1.3 \mathrm{~km}$ upstream from the fault. The T2 surface also has two sections that are apparently tilted southwards, one at $800-900 \mathrm{~m}$ from the fault with a gentle slope of $\sim 1.5^{\circ} \mathrm{S}$ and a second in the $100-200 \mathrm{~m}$ closest to the fault, with a slope of $\sim 4^{\circ} \mathrm{S}$. These two sections are coincident with the southwardtilted sections of T1. Near the fault, the T2 surface is $\sim 36.3 \pm 1.7 \mathrm{~m}$ above the current river level (Figure 4). However, projecting the river-parallel part of the terrace gradient to the current fault trace suggests the terrace is $\sim 21.8 \pm 1.4 \mathrm{~m}$ above the present river level at the fault. The different degree of uplift on each section of the terrace surface is likely to be due to changes in the fault dip, with a steeper dip under the section nearest the fault trace. We note that the fan aggradation during $\mathrm{T} 1$ formation will have buried the footwall remnant of T2, so the observed uplift is a minimum since abandonment.

T3 is mainly preserved on the eastern bank, though there is a small remnant on the western side (Figures 3 44). The terrace is not preserved in the vicinity of the fault scarp, so estimating the total displacement requires significant extrapolation giving large associated errors. At the location of our sample (A3, Figure 3d), the eastern and western terrace remnants are at heights of $\sim 42 \mathrm{~m}$ and $\sim 35 \mathrm{~m}$ above the modern footwall surface respectively; we attribute this difference to the asymmetry of the drainage and the river not being perpendicular to the fault, but they may also be two separate sub-terraces. Projecting the gradient of the terrace to the present fault surface trace, we estimate a minimum uplift of $45 \pm 5 \mathrm{~m}$ since abandonment for the larger remnant.

Only a small remnant of T4 exists at a significant distance from the surface trace so the uplift is poorly constrained. Scaling the T1 profile up to T4, we estimate a minimum displacement of $53 \pm 5 \mathrm{~m}$. There are several locations where subsidiary terraces were also noted, but as they have minimal extent we do not analyse them further.

In addition to the deformation of the terrace surfaces, we also note a deflection of the 
river gradient. The river shows a short wavelength step of $\sim 2.5 \pm 0.5 \mathrm{~m}$ (significant against the noise level, Figure 4), which has not migrated upstream significantly from the fault. There is no bedrock visible in the modern stream bed and the Neogene sediments are very soft and unlikely to generate a material contrast strong enough to cause this deflection purely due to a change in lithology. It is likely therefore that this deflection arises from motion on the fault, though given the relatively diffuse nature of the deflection, it is not possible to distinguish whether it has been generated by continuous creep, a palaeoearthquake, or a combination of both mechanisms.

\subsubsection{Terrace Deformation}

Approximately $200 \mathrm{~m}$ south of the scarp, T1 shows a kink in height by $1.7 \pm 0.3 \mathrm{~m}$ over a distance of $\sim 70 \mathrm{~m}$. At the corresponding point in T2, the remainder of the terrace south of the kink changes gradient from approximately river parallel to $4.5^{\circ}$ relative to the river gradient, dipping to the south (away from the fault trace). We attribute this feature to a steepening of the fault dip towards the surface in the uppermost 50-100 m of sediments. This step preserved in both terraces closely resembles fold scarps generated by fault-bend folding (e.g. Le Béon et al. 2014). The step has resulted in a distinctive short wavelength ( $\sim 100 \mathrm{~m})$ raised topographic feature in the immediate hangingwall of the fault along much of the rangefront (Figure 2b), though it has been eroded in places by landsliding of the soft Neogene sediments.

Further into the hangingwall, we noted a second back-tilted section in both T1 and T2, which we again attribute to a steepening of the fault under this section ( $\sim 800 \mathrm{~m}$ from the fault trace). Under this model, we would expect the ratio of the step offset in T1 to the step offset in $\mathrm{T} 2$ to equal the ratio of total fault slip since abandonment of each terrace. Significant noise due to erosion of the terrace surface gives large errors, but we estimate a ratio of $1.9 \pm 0.4$ i.e. T2 records approximately twice as much slip as T1 (Figure 4). For comparison, we estimate the ratio of the elevation of the terrace surfaces relative to modern river level either side of the fold scarp giving $2.16 \pm 0.09$ (north) and $2.25 \pm 0.15$ (south), the 
same as the ratio of slip estimated from the fold scarps (within error). This suggests that the elevation of the T2 terrace above present river level is a good measure of the total uplift of T2 since abandonment (within error), so there may have been only minimal burial of this surface in the footwall $(<20 \%$ of the uplift).

\subsubsection{Rc1: Terrace Chronology}

We excavated a pit into each terrace surface, choosing locations to minimise the likelihood of post abandonment deposition or erosion i.e. well away from up-slope risers or stream channels (locations A1-A4 in Figure 3d). We also sampled from a stream cut exposure in the footwall surface $(\mathrm{A} 0)$. Though attempts were made to measure quartz OSL (opticallystimulated luminescence) and feldspar IRSL (infra-red stimulated luminescence) ages from the luminescence samples (OSL1 and OSL2 from A0 and A1), the sample material proved unreliable for both methods in both samples. Quartz measurements showed very dim signals lacking a rapidly bleaching "fast" component. Feldspar measurements were brighter, but showed larger inter-aliquot spread and large residuals after bleaching, suggesting incomplete bleaching prior to deposition - ages are shown in Table 1, but the interpretation is unclear. We therefore discuss only radiocarbon ages from this catchment. As there was no discrete identifiable organic matter available, we were restricted to bulk dating of organic rich sediment samples from within the terrace deposits - generally, dark consolidated palaeo-soil clasts were used (Table 1).

In the footwall, a river cut exposes the uppermost stratigraphy which consists of a soil cap of $\sim 40 \mathrm{~cm}$ overlying angular gravels (up to $\sim 15 \mathrm{~cm}$ diameter) with occasional coarse sand lenses Figure 5. However only the uppermost $2 \mathrm{~m}$ is exposed, so the depth of the Neogene contact in the footwall is unknown.

The terrace surface of $\mathrm{T} 1$ in the hangingwall consists of a $\sim 35 \mathrm{~cm}$ soil cap on top of gravels, which were estimated to be $\sim 2-4 \mathrm{~m}$ thick, lying unconformably on top of the red Neogene sediments (observed in river cuttings, Figure 5). Given the similar gravel cap in the footwall and hangingwall, it is likely that the surface in the footwall represents the correlated 
T1 surface. Our only successful age constraint comes from radiocarbon bulk samples, which provide estimates of the pre and post abandonment ages. Sample C3 from the base of the soil layer (depth $\sim 35-41 \mathrm{~cm}$, Figure 5) at A1 was a very dark organic rich soil layer, which yielded a calibrated age of 4.0-4.2 ka BP. Thompson et al. (2002) suggest that samples from the base of the post-abandonment deposits generally give a tight post-date on terrace abandonment. Sample C4 from a depth of $\sim 58 \mathrm{~cm}$ at A0 was a $\sim 6 \mathrm{~cm}$ soil clast embedded within the gravel matrix, which yielded a calibrated age of 9.6-9.7 ka BP, a pre-date on terrace abandonment. As these gravels cover the footwall remnant of T2, this must also post-date the abandonment of $\mathrm{T} 2$.

T2 consists of a thicker soil development of $\sim 60 \mathrm{~cm}$ overlying red clay, with a poorly defined interface. The red clay contains occasional gravels $(<10 \mathrm{~cm})$. Given the thick soil development on the T1 terrace, a significant proportion of the soil development on this terrace is likely to post-date T1 too. Sample C5 (pit A2), a consolidated organic rich soil clast treated as a bulk sediment sample was extracted from within the mixed gravel and clays at a depth of $\sim 124 \mathrm{~cm}$ and yielded a calibrated age of 14.2-14.9 ka BP. Given that this sample was within the upper part of the pre-abandonment deposits, it suggests that the terrace was abandoned after $\sim 14.5 \mathrm{ka}$.

T3 showed a very similar stratigraphy to T2 with poorly defined stratigraphic boundaries. Below a $\sim 40 \mathrm{~cm}$ soil cap, there was a further $\sim 40 \mathrm{~cm}$ of very uniform red clay without clasts. Beneath $80 \mathrm{~cm}$ depth, there were sparse fine gravels $(<3 \mathrm{~cm})$ in a clay matrix, with occasional cobbles up to $\sim 20 \mathrm{~cm}$. Sample C6 (pit A3), a soil clast embedded in the uniform clay at a depth of $\sim 76 \mathrm{~cm}$, yielded a calibrated age of 28.2-28.7 ka BP. Sample C7 (pit A3) at a depth of $88 \mathrm{~cm}$ yielded a calibrated age of 10.4-10.7 ka BP. These two samples are in reverse stratigraphic order, with a very large difference in age and one of similar age to C5 on T2. This suggests that either C6 was eroded from up-slope and redeposited here during soil development or post-depositional contamination has occurred for one or both samples. T4 has a $30 \mathrm{~cm}$ soil cap, and also merged slowly into a uniform red clay, which becomes interspersed with occasional small clasts below $\sim 85 \mathrm{~cm}$. Two bulk samples, C8 of bulk soil 
and C9 of bulk clay, yielded calibrated ages of 8.8-9.0 ka BP and 12.7-12.8 ka BP respectively - similar to samples from T2 and T3.

\subsubsection{Rc1 Terraces - Summary}

Topographic profiles through the DEM of the Rc1 river valley with the present river gradient removed, reveal that $\mathrm{T} 1, \mathrm{~T} 2, \mathrm{~T} 3$ and $\mathrm{T} 4$ are offset vertically by $\sim 10, \sim 22, \sim 45$ and $\sim 53$ metres respectively, relative to the present day footwall surface (Figure 4). In T1 and T2 we note the back-tilting of the terrace surface in two locations, suggesting a progressive steepening of the fault plane in the uppermost $500 \mathrm{~m}$ of sediments, though we cannot constrain the absolute dips. Mild folding of the terrace surface in the 100-200 m south of the fault trace suggests a steep dip in the near surface, while the sinuous fault trace along the rangefront suggests that although the uppermost $\sim 100$ m may be relatively steep, the section beneath most of the terraces should have a relatively low dip.

Radiocarbon samples constrain the age of the T1 surface to 4.1-9.7 ka, though as suggested by Thompson et al. (2002), we take the lower end of this as forming a close post-date on terrace formation, at $\sim 4.1 \mathrm{ka}$. This is similar to a prominent terrace dated at $4.2-5.2 \mathrm{ka}$ in central Kyrgyzstan by Campbell (2015). Radiocarbon samples from the higher terraces proved more contextually difficult to interpret, but a sample from the gravel-clay interface on T2 gave an age of $\sim 14$ ka. This would be consistent with T2 being the widespread QIII(3) terrace observed in Kyrgyzstan which is dated at 13.5-15.7 ka (Thompson et al. 2002; Landgraf et al. 2016).

With the exception of C6 which is out of apparent stratigraphic order, the ages from T3 and T4 are not significantly older than those observed for T2, suggesting that there was a major period of soil development at $\sim 9-12 \mathrm{ka}$, responsible for all of these soil deposits; consistent with formation in the stable post-glacial conditions. Alternatively, extensive groundwater flow can result in post-depositional exchange of the carbon content, especially in bulk soil samples. The age inversion of C6 further suggests that reworking of material may 
have occurred. Estimates of uplift and shortening rates based on the terrace sequence (and predominantly onthe lower terraces $\mathrm{T} 1$ and T2) are discussed in $\$ 2.4$

\subsection{River Catchment 2 - Border Valley (Rc2)}

The Pléiades DEM allowed us to extend our survey over a much larger area than was readily achievable by field survey. The catchment Rc2 lies on the border between Kazakhstan and Kyrgyzstan, and is therefore difficult to investigate thoroughly with a field survey. However, the DEM reveals the exceptional level of preservation at this site, with 7 separate terrace levels identified (Figure 6), sequentially uplifted by up to $\sim 300 \mathrm{~m}$ above present river level (Figure 7). The degree of preservation is likely due to the river having the largest catchment of any along the rangefront $\left(\sim 1000 \mathrm{~km}^{2}\right)$. We label the terraces consistent with those at Rc1 and Rc3, based on uplift and morphology, but this correspondence is only approximate.

There is a large scarp at a primary fault strand at the rangefront, but the T2 surface also shows a series of smaller offsets in the hangingwall, suggesting that a fraction of the motion is distributed across the terrace surface. Each of the terraces also show a broad warping in the immediate hangingwall over a wavelength of $\sim 1.5 \mathrm{~km}$, suggesting either that the fault dip flattens slightly towards the surface in the uppermost 1-2 km (Figure 6, 7), or that mild folding of the hangingwall occurs.

The lowest terrace surface T0, records a vertical offset of just $4.8 \pm 0.6 \mathrm{~m}$ (Figure 76), the smallest observed along the rangefront. This young terrace is only well preserved within $\sim 500 \mathrm{~m}$ of the fault, so we are unable to assess any contributions due to folding. Additionally, we see a remnant of an intermediate terrace further upstream, displaying an offset approximately half that of T2, which may be the T1 surface. This surface is displaced to $16.7 \pm 2.5 \mathrm{~m}$ above the present river level. Given the warping of the terrace surfaces, T0 could instead be the T1 surface, but with the surface slip reduced by slip on the secondary structures.

The T2 terrace at Rc2 is very well preserved, extending $\sim 2.5 \mathrm{~km}$ upstream, with very little incision/degradation. Given the similar level of preservation and degree of uplift, we 
liken this terrace to the $\mathrm{T} 2$ terrace at Rc1. At the fault trace, we estimate a vertical offset of $\sim 20 \mathrm{~m}$, but given the general folding of the terrace over the $2 \mathrm{~km}$ wavelength, we estimate a maximum uplift of $26 \pm 1.8 \mathrm{~m}$ for $\mathrm{T} 2$.

The upper terraces T3-9 show similar shapes, though with a general progression towards the basin of the point of maximum uplift of the terrace; we attribute this progression to the advection of topography by fault motion. We estimate peak displacements of $75 \pm 7 \mathrm{~m}$, $102 \pm 4 \mathrm{~m}, 190 \pm 11 \mathrm{~m}, 304 \pm 22 \mathrm{~m}$ for terraces T5, T6, T8 and T9 respectively.

\subsection{Results: River Catchment 3, Kyrgyzstan}

Catchment Rc3 is at the western end of the Karkara fault segment, in Kyrgyz territory where the fault surface trace is $\sim 15 \mathrm{~km}$ from the Cenozoic/Palaeozoic contact (Figure 2). The Rc3 river has a large catchment $\left(\sim 360 \mathrm{~km}^{2}\right)$ and low gradient $\left(0.9^{\circ}\right)$, giving rise to large fan structures and hence terrace surfaces.

\subsubsection{Rc3: Terrace Offsets}

Figure 8 shows a detailed map of the major terrace surfaces observed at Rc3. The most prominent terrace shows a similar morphology to the T2 terrace at Rc1 and Rc2 and a similar scarp height, so we label this terrace T2 consistent with the previous sections. We also identify a smaller terrace remnant $\sim 700 \mathrm{~m}$ from the fault trace which is approximately half as high above the present river level as T2. We interpret this remnant as T1. The paired T2 terrace is well preserved, extending $\sim 10 \mathrm{~km}$ upstream from the main fault trace (though only $\sim 4 \mathrm{~km}$ is captured within the DEM, Figure 8a). A profile across the primary scarp on the west side of the river (Figure 8c), shows an offset of $13.0 \pm 0.4 \mathrm{~m}$ relative to the modern footwall. In addition to the main fault strand, we also observe a smaller scarp $\sim 400 \mathrm{~m}$ south of the main scarp with an offset of $2.4 \pm 0.4 \mathrm{~m}$ (Figure 9d). Incorporating the secondary scarp offset, we estimate a total vertical offset since abandonment of $15.4 \pm 0.8 \mathrm{~m}$. On the eastern side of the river channel, the fault trace splits in the older surfaces, forming a number of smaller strands spread over $\sim 1.5 \mathrm{~km}$. 
On the eastern riverbank, a flight of four higher terraces is preserved, uplifted by up to $150 \mathrm{~m}$ above the current river channel. However, the fault is split into several strands (Figures 8 9), so each terrace surface shows scarps in several places. The high resolution Pléiades DEM enabled us to map terraces not visible in the field or satellite imagery. A perspective overview of the terrace system (Figure 9a) shows that these higher terraces are tilted eastwards, away from the main river channel, resulting in small channels which have formed at the base of the riser for each terrace. This might be due to curvature in the initial terrace surface at abandonment or differential uplift across the terrace system i.e. the terraces are folded but the fold axis plunges eastwards.

Scaling the peak displacement of $\mathrm{T} 2$ to match that of each of the higher terraces, we assign plausible labels to the higher terraces consistent with those at Rc2, T4-T8. However given the switching fault strands and the missing intermediate terraces there is considerable uncertainty in this labelling, so we are cautious of any interpretation relating the higher terraces to other sites. We estimate maximum offsets of $56 \mathrm{~m}, 78 \mathrm{~m}, 100 \mathrm{~m}, 120 \mathrm{~m}$ and $150 \mathrm{~m}$ for the T4, T5, T6, T7 and T8 surfaces respectively (Figure 8d). We note that all the old terraces show similar displacement across the southern fault strand, while the older terraces show progressively more uplift on the northern strand than the younger ones. The youngest terraces T1 and T2 are continuous across the northern strand and are not offset acorss it. This suggests that fault motion used to be accommodated by the northern strand, but switched to the southern strand since the abandonment of $\mathrm{T} 2$.

\subsubsection{Rc3: Terrace Chronology}

The T2 terrace consists of a gravel bed deposited on a Neogene strath (exposed only in the river bed) capped with a thin $(\sim 30 \mathrm{~cm})$ post-abandonment soil development. We sampled the surface via a pit near the primary fault trace, well away from any hillslopes above to minimise chance of redeposited material. The terrace gravels were broadly divided into two units; the upper with a soil matrix and the lower with a coarser sandy matrix, both with rounded clasts up to $<35 \mathrm{~cm}$ (Figure 9e,f). As at Rc1 (\$2.1), we found two pockets of dark, 
organic rich sediment embedded within the gravels. $\mathrm{C} 1$ at a depth of $\sim 86 \mathrm{~cm}$ yielded a calibrated age of 4.82-4.96 ka, while $\mathrm{C} 2$ at a depth of $105 \mathrm{~cm}$ yielded a calibrated age of 26.99-27.45 ka. The large disparity in ages suggests post depositional mixing or significant groundwater leeching. Inspecting high resolution optical imagery available after the field investigation (Bing Maps), we note that there are remnant plough furrows on the majority of the terrace surface. This suggests the large, flat terrace surfaces were intensively farmed in the Soviet era so the upper part of the terrace may have undergone significant mixing in the last $\sim 100$ years.

\subsection{KRF Slip Rate}

Figure 10 summarises the terrace ages we have constrained at Rc1 through radiocarbon dating, plotting terrace uplift against age. Based on the uplift of T1 and T2, we estimate an uplift rate of $\sim 1.5-2.6 \mathrm{~mm} / \mathrm{yr}$ (dashed lines, Figure 10). The ratios of the heights of $\mathrm{T} 1$ and T2 above the present river levels (\$2.1) suggest that there was minimal burial in the footwall of the T2 surface, though the uplift of the T2 surface may still be underestimated by up to $20 \%$ within the errors observed. The lower uplift rate suggested by T2 would suggest that some footwall burial may indeed have occurred. Also shown are the ages from the upper terraces T3 and T4 at Rc1 (grey points), which are mostly anomalously young and suggest a period of enhanced soil formation after the abandonment of T2. However, C6 would be consistent with a similar uplift rate to those suggested from $\mathrm{T} 1$ and $\mathrm{T} 2$, suggesting that it may have been unaffected by post-depositional carbon exchange.

Estimating a slip-rate and shortening rate for the fault remains difficult as we were unable to find fault exposure to estimate the fault dip. The relatively sinuous fault trace at a local scale suggests a gentle dip in the uppermost $100 \mathrm{~m}$ of sediment, though this is likley to steepen with depth, both as a ramp within the Cenozoic sediment sequence, and also as high-angle faulting within the basement rocks (c.f. basement faults are often found to be $>45^{\circ}$ at depth, Avouac \& Tapponnier 1993). Using Monte-Carlo simulations (Thompson et al. 2002), we estimate probability distribution functions (PDFs) for the slip-rate and 
shortening rate based on conservative estimates for the fault dip, assuming that slip along the fault plane remains constant. In the shallow subsurface we take a dip range of $25-45^{\circ}$ (uniform PDF). The fault most likely steepens within the basement so we assume a dip of $45-60^{\circ}$ at depth.

We assume that $\mathrm{T} 1$ is well dated by sample $\mathrm{C} 3$, while $\mathrm{T} 2$ is bracketed with a uniform probability density function by the ages of $\mathrm{C} 4$ and $\mathrm{C} 5$, yielding a slip-rate of $3.5_{-0.4}^{+1.7} \mathrm{~mm} / \mathrm{yr}$ (or $2.8_{-0.7}^{+1.4} \mathrm{~mm} / \mathrm{yr}$ based on T2, Figure 10 ). We therefore estimate the shortening accommodated by the basement fault based to be $2.3_{-0.6}^{+1.0} \mathrm{~mm} / \mathrm{yr}$ from $\mathrm{T} 1\left(1.6_{-0.5}^{+1.1} \mathrm{~mm} / \mathrm{yr}\right.$ based on T2, 95\% confidence bounds based on estimated PDFs, Figure 100.

\section{KEGEN BASIN FOLD (KBF)}

Approximately $12 \mathrm{~km}$ north from the main rangefront, a fold structure runs NE-SW through the middle of the Kegen Basin (KBF, Figures 1, 2, 11, 12), with a relief of 200-300 m above the basin floor. It may represent a foreland propagation structure from the main rangefront in a style similar to many basin folds observed in nearby Kyrgyzstan and China (e.g. Thompson et al. 2002: Charreau et al. 2008; Goode et al. 2011). The degree of bed rotation (described below) suggests that significant total slip has occurred, but the lack of Palaeozoic outcrop suggests that the fault is restricted to the basin sediments. Evaporitic layers are present in the deepest parts of the Cenozoic structure (identifiable in the satellite imagery as highly reflective in all bands), which may act as a decollement at depth (e.g. Bullen \& Burbank 2001). We investigate the KBF, identifying Quaternary scarps along the northern edge and broad warping of a river terrace which crosses a large portion of it.

\subsection{KBF Structure and Geomorphology}

Near the town of Karkara the KBF is cut by the Karkara river (large $1500 \mathrm{~km}^{2}$ catchment), which has eroded a deep channel through the fold. River cut exposures into well bedded, steeply dipping Cenozoic deposits are preserved widely along the eastern riverbank and in several locations on the west (Figures $12 \mathrm{a}, \mathrm{b}, 13 \mathrm{a}$ ). We measured bedding orientations of 
the Cenozoic sediments, in a profile nearly perpendicular to the fold, spanning the first $3.5 \mathrm{~km}$ south of the surface fault trace. The beds dip moderately to the north near the fault $\left(\sim 45^{\circ}\right)$, steepening southwards to approximately vertical at $\sim 3.4 \mathrm{~km} \mathrm{~S}$ of the fault trace, before switching to dip to the south (Figure 12 c). Further south, the Cenozoic beds are no longer well exposed because the river is less constrained by the channel through the fold core, splitting into a number of smaller tributaries each with less incision such that there are no natural exposures. Comparing the observed bedding dips to the topographic section (Figure 12), we estimate a folding wavelength of $\sim 6.5 \mathrm{~km}$, though much of the backlimb of the fold has been eroded.

A prominent terrace on the eastern river bank (Figure 13 a), is well preserved in both the footwall and approximately $2 \mathrm{~km}$ into the hangingwall. Unfortunately only one short terrace remnant was observed to the south of the fold axis, which we are unable to correlate to other terraces so we can only estimate the deformation in the fore-limb of the fold. The terraces consist of a strath cut into the Cenozoic beds overlain unconformably by river gravels (Figure 13). Post terrace-abandonment, a loess cap (typically $0.5-2 \mathrm{~m}$ ) accumulated, followed by a soil development (0.1-0.5 m). We use kinematic GPS to measure a long profile of the terrace surface (Figure 12, location in Figure 11b). This was performed by car along the road on the terrace surface, so the road embankment has resulted in an artificial smoothing of the surface scarp. The terrace surface does not capture the crest of the folding deformation, but we observe that folding has generated at least $\sim 16 \mathrm{~m}$ of uplift. Figure 13 f also shows a higher resolution pair of profiles across the fault scarp at the surface trace, from which we estimate a vertical offset of $10.0 \pm 0.5 \mathrm{~m}$, giving a minimum total uplift of $\gtrsim 26 \mathrm{~m}$ since terrace abandonment.

\subsection{KBF Chronology}

Radiocarbon and OSL/IRSL samples were collected from the prominent river terrace crossing the KBF (sampling locations in Figure 11). The individual luminescence and radiocarbon ages are summarised in Tables 13 . 


\subsubsection{Radiocarbon Ages}

Samples C10 and C11 (sites A1, A2, Figure 11) consisted of amalgamated small fragments of gastropod shell from a sand lens within the gravels (Figure 13e), and yielded calibrated ages of 35.7-36.5 ka BP and 38.2-39.1 ka BP respectively. Gastropod shell has been shown to sometimes have significant inheritance due to the incorporation of calcium carbonate from the surrounding environment, or failure to behave as a closed system after burial (e.g. Pigati et al. 2010). In the nearby Saty valley, several modern (live) shells were dated at equivalent radiocarbon ages of 0-1000 yrs BP (Abdrakhmatov et al. 2016). Additionally, in dating amalgamated fragments, there is no well defined heritage, so there may be further inheritance due to post-death redeposition - dating of amalgamated small shell fragments by Abdrakhmatov et al. (2016) yielded ages of $4.5 \mathrm{ka}$ and 8 ka for samples embedded in a medieval soil. As both $\mathrm{C} 10$ and $\mathrm{C} 11$ are within the terrace gravels and likely have significant inheritance, they only pose an upper limit on the abandonment age of the terrace.

\subsubsection{Luminescence Ages}

Sample OSL3 was collected from the base of the loess layer in a small channel of mixed loess/silt, cut into the terrace gravels (Figure 13.). OSL4 was collected from a coarse sand lens in the uppermost terrace gravels, deposited prior to terrace abandonment (Figure $13 \mathrm{~d}$ ). Both samples exhibited reasonably bright quartz OSL signals and dose recovery tests showed that in most cases a known dose could be recovered within $10 \%$ of the administered value without a systematic or strong trend with preheat temperature (see supplementary information S1). Though OSL4 was able to broadly recover a consistent dose, it showed significantly more scatter than OSL3. Of the 37 aliquots measured for OSL3, 17 were rejected on the basis of poor recycling ratios and a further 2 for excessive recuperation; the remaining 18 were used to calculate the equivalent dose. The poor recycling and recuperation were most likely due to the dominance of medium and slow components in those aliquots (see Supplement S1). OSL4 seemingly performed better, with only 1 of 25 aliquots rejected. We estimate

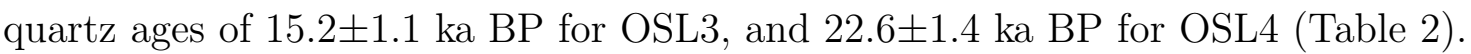


${ }_{486}$ in the uppermost crust. 


\section{GPS CONSTRAINTS ON FAULT CREEP}

To estimate a present day geodetic slip-rate on the Karkara rangefront and investigate the possibility of fault creep, we fit an edge dislocation model to two N-S profiles through the regional GPS velocity field (Zubovich et al. 2010). The solution for the horizontal displacements $\left(u_{x}\right)$ at the surface due to a dipping semi-infinite edge dislocation at depth $d$ in a uniform elastic halfspace (e.g. Segall 2010), is described by:

$$
\begin{gathered}
u_{x}=\frac{s}{\pi}\left(\cos \delta \arctan \eta+\frac{\sin \delta-\eta \cos \delta}{1+\eta^{2}}\right), \\
\eta=\frac{x-d \cot \delta}{d},
\end{gathered}
$$

where $s$ is the fault slip, $d$ is the depth to the edge dislocation, $\delta$ is the fault dip and $x$ is the surface coordinate relative to the fault surface projection. This solution predicts surface displacements for a fault plane locked down to a depth $d$ and stably sliding below. As the problem is linear, the case of a partially locked fault (e.g. with a slower slip rate on the upper section than the lower section) can be treated as two planes slipping at different rates superimposed to add to the correct slip rates. Similarly, changes in fault geometry can be modelled as multiple edge dislocations superimposed.

We investigate profiles P and Q (Figure 1 $\mathrm{b}$ ) through the regional GPS data of Zubovich et al. (2010), chosen to coincide with the highest density of stations within a swath of $\pm 10 \mathrm{~km}$. Before fitting the data, we subtract a regional strain rate of $0.6 \times 10^{-15} s^{-1}$ observed for this region by England \& Molnar $(2015)$ - this extra component strain must be accommodated by the faults of this region but is smoothly distributed and so cannot be attributed to any individual fault.

\subsubsection{Profile $Q-Q^{\prime}$}

Profile Q shows little or no curvature on either side of the fault, suggesting minimal locking. We know from Rc1 (\$2.1) that the geometry of the fault in the uppermost $\sim 1 \mathrm{~km}$ of 
sediments is not entirely constant, so the exact surface projection of the fault plane at seismogenic depths is unlikely to coincide with the surface fault trace. The extreme scenario for determining the locking depth is that the fault projects to half way between the two GPS stations either side of the fault, so we use that fault location in order to put an maximum bound on the locking depth.

We first perform a linear inversion for the slip rate with a zero locking depth and an assumed fault dip of $45^{\circ}$, to estimate an approximate slip rate. This is refined by a grid search in locking-depth - slip-rate space across a reasonable range. Our model estimates a shortening-rate of $3.2 \pm 0.3 \mathrm{~mm} / \mathrm{yr}$, with a maximum locking depth of $\sim 1.5 \mathrm{~km}$. The uppermost $1-2 \mathrm{~km}$ is primarily composed of Cenozoic sediments, which are less likely to be able to store significant elastic strain than the underlying crystalline basement rocks (e.g. Tse \& Rice 1986; Marone 1998), so it is likely that creep extends all the way to the surface. Figure 14a shows the regional GPS data projected onto the line Q-Q', with our best fit model overlain in red. The point in grey was excluded from the inversion, as it implies localised extension across the thrust, though the model prediction is still within the $95 \%$ error bound; the resultant rms misfit is $0.28 \mathrm{~mm} / \mathrm{yr}$. The black line shows a model locked to a depth of $5 \mathrm{~km}$, demonstrating that even relatively shallow locking is a poor fit to the data. As creep appears to reach the surface at the full rate, the model is insensitive to the fault dip. Estimates of the slip-rate are dip dependent, but our minimum of $\sim 3.2 \mathrm{~mm} / \mathrm{yr}$ makes it one of the fastest known in the Tien Shan.

\subsubsection{Profile $P-P^{\prime}$}

Profile P shows a large step offset at the fault (location well constrained), but it also shows a broader deflection towards the fault over a wavelength of $\sim 10 \mathrm{~km}$ either side. This could arise from two potential sources; partial locking of the upper fault plane and changes in fault geometry. We test both of these cases and compare to that of a planar fault creeping all the way to the surface.

Figure $14 \mathrm{~b}$ shows the regional GPS data projected onto the line $\mathrm{P}-\mathrm{P}$ ' with our three best 
fit models overlaid. A simple planar fault creeping to the surface at the full slip rate yields a shortening rate of $2.7 \pm 0.6 \mathrm{~mm} / \mathrm{yr}$, but does not give a good fit to the near fault stations (rms misfit $0.36 \mathrm{~mm} / \mathrm{yr}$ ). If we allow partial locking above a depth $\mathrm{D}$, we can solve for the degree of locking $(\epsilon)$ and D. This model predicts a shortening rate of $2.9 \pm 0.7 \mathrm{~mm} / \mathrm{yr}$, with $\epsilon=0.7 \pm 0.2$, a poorly resolved locking depth of $6_{-2}^{+3} \mathrm{~km}$, and an $\mathrm{rms}$ misfit of $0.36 \mathrm{~mm} / \mathrm{yr}$. Lastly, we superimpose a hypothetical model of changing geometry, with a constant slip rate creeping to the surface. The data are not sufficient to constrain an inversion for the geometries of such a model, but taking an example of a $45^{\circ}$ fault at depth, which steepens to $60^{\circ}$ in the uppermost $7 \mathrm{~km}$ gives an rms error of $0.34 \mathrm{~mm} / \mathrm{yr}$, slightly lower than either discussed above (Figure 14:).

We conclude that a single creeping fault does not provide a good fit to the available data here and underestimates the slip rate, whereas a partially locked fault (slipping at $70 \%$ of the full slip rate) or a flat-ramp geometry provide a better fit, with a shortening rate of $2.9 \pm 0.7 \mathrm{~mm} / \mathrm{yr}$. Given the very close proximity of the stations either side of the fault on this profile, a significant fraction of the fault slip is unambiguously reaching the surface at the mapped fault strand. It is clear from both of the profiles discussed here that the KRF is creeping, most likely at the full slip-rate resolvable from GPS at the present day (discussed further in $\$ 5.1)$.

\subsection{GPS vs Late Quaternary Rate}

Elastic halfspace modelling of the regional GPS velocity along profiles $\mathrm{P}$ and $\mathrm{Q}$ gives a consistent shortening rate estimate of 2.9-3.2 mm/yr for both profiles. A careful inspection of the regional GPS station locations shows that for profile Q (Figure 1), the only station between the KBF surface trace and the KRF is a single one near the core of the fold that will record little of the shortening accommodated by the KBF. Both profiles therefore include any motion accommodated by both the KRF and the KBF and cannot distinguish between them.

In $\$ 2.4$ we estimated that the KRF has accommodated $1.1-3.3 \mathrm{~mm} / \mathrm{yr}$ of shortening in the 
late Quaternary. Without further estimates of the folding geometry at the KBF, we cannot convert our uplift estimate into a corresponding shortening rate - however, given its clear expression in the geomorphology, it is likely that it contributes a non-negligible component of shortening. Given the significant error margins in geochronology and fault geometry, our estimates of the shortening in the Late Quaternary are consistent with the geodetic rate. This suggests that the loading rate on these two faults has remained unchanged through time and, as they appear to together accommodate the $2.9-3.2 \mathrm{~mm} / \mathrm{yr}$ of shortening seen in the GPS, it also suggests that they are creeping at their average long-term rate.

\section{DISCUSSION}

\subsection{Creep on a Mature Fault}

Modelling of the regional GPS data (\$4) suggest that the KRF is either creeping or locked to shallow depths of $<3-5 \mathrm{~km}$. However, the time period of GPS observation is very short compared to the seismic cycle in the region (typically 1-5 ka, e.g. Abdrakhmatov et al. 2001. Grützner et al. 2017a) so it is unclear whether the present creep is indicative of the long term fault behaviour.

In addition to the GPS data, the shape of the Late Quaternary fault scarp also hints at formation by creep over a longer timescale. The shape of the scarp in T1 at catchment Rc1 does not conform to a typical scarp diffusion model (e.g. Wallace 1977; Avouac 1993). The upper limb of the scarp shows a broadly curved shape as might be expected, but the lower limb shows very little curvature where it meets the footwall and the face of the scarp is very steep $\left(\sim 21^{\circ}\right.$, Figure 4$)$. This scarp shape instead fits the profile of a fresh scarp, with mild folding of the hangingwall and a gravity-controlled face at the base (e.g. Carretier et al. 2002). As the scarp would be large for a single event and there are no known events over the past hundred years on this fault, the scarp shape is consistent with continuous formation by fault creep, maintaining the 'fresh' appearance and gravity controlled face.

Most observations of creeping faults are from the decades to centuries following major earthquakes upon them (e.g. Cohn et al. 1982; Reilinger et al. 2000; Lienkaemper et al. 2001). 
A number of major plate margin faults are also known deform by creep without associated earthquakes, for example sections of the North Anatolian fault (e.g. Kaneko et al. 2012), the Longitudinal Valley Fault (e.g. Thomas et al. 2014) and the San Andreas Fault (e.g. Steinbrugge et al. 1960; Titus et al. 2006). However, very few intraplate faults are observed to creep without a known prior earthquake (e.g. Jolivet et al. 2012; Copley \& Jolivet 2016). The only known large historical earthquake close to the study area is the 1889 Chilik earthquake attributed to the Saty fault (e.g. Abdrakhmatov et al. 2016), see Figure 1 for its epicentre. There are no other known earthquakes which have occurred in the region of the Karkara Rangefront in the last few hundred years, but historic records in the region are generally short and poorly documented (Campbell et al. 2015).

The Main Terskey Front (MTF) is almost $600 \mathrm{~km}$ long, and at the longitude of the KRF it has considerable relief across the it. Apatite fission track (AFT) and apatite U-Th$\mathrm{Sm} / \mathrm{He}(\mathrm{AHe})$ ages suggest that the widespread late Cenozoic deformation initiated in the Tien Shan at $\sim 25$ Ma (e.g. Hendrix et al. 1992; Yin et al. 1998), though recent studies in the vicinity of some of the major inherited structures suggest that tectonic deformation may have begun to occur as early as $\sim 45-55 \mathrm{Ma}$ (Glorie et al. 2011). Macaulay et al. (2014) suggest that deformation initiated on the inherited structures best able to accommodate the regional deformation, including the MTF on the northern front of the Terskey Range. Samples from the Terskey Range show an intensification in the late Cenozoic, driven by increased regional shortening (5-3 Ma, Sobel et al. 2006; Selander et al. 2012; Macaulay et al. 2014). The AFT data show rapid bedrock exhumation in the Terskey Range over the late Cenozoic, our results show a rapid slip-rate on the KRF through the late Quaternary, and the regional GPS suggest rapid slip at the present. The MTF therefore appears to have played and be playing a major role in the development of the Tien Shan - a very mature fault that has accommodated significant total displacement. This is consistent with the other major examples of long term creep on intraplate faults (e.g. San Andreas, North Anatolian Fault), suggesting that the fault maturity is linked to its strength (Bürgmann \& Dresen 
612

613

2008), allowing deformation by aseismic creep (e.g. Chester et al. 1993; Kaneko et al. 2012, Carpenter et al. 2011).

\subsection{Seismic Hazard}

The observed shortening rate makes the Karkara Rangefront one of the fastest faults in the ॠTien Shan, though even faster rates are observed further SW in the Pamir Arrowsmith \& Strecker 1999). Our observations show that most or all of the slip is reaching the surface as creep, suggesting that strain accumulation across the fault is likely to be minimal at present. Seismic hazard assessments based on the regional strain rate field (e.g. Holt et al. 2005) may overestimate the seismic hazard in the area, as a significant fraction of the strain is being released aseismically and creep manifests as an extremely high strain rate. However, the capacity for creeping faults to sustain large earthquakes is debated (e.g. Harris 2017; Chen \& Bürgmann 2017) and as noted above, it is not clear whether creep is the long term deformation mechanism.

Contemporary studies of the late-Quaternary faulting in the Tien Shan have mostly focused on the western and northern ranges of Kyrgyzstan (e.g. Burtman et al. 1996; Burbank et al. 1999; Abdrakhmatov et al. 2002; Thompson et al. 2002; Oskin \& Burbank 2007; Selander et al. 2012; Goode et al. 2014; Landgraf et al. 2016) and the Chinese Tien Shan (e.g. Burchfiel et al. 1999; Hubert-Ferrari 2005). Fewer studies have focused on the Tien Shan of SE Kazakhstan (e.g. Arrowsmith et al. 2016; Abdrakhmatov et al. 2016; Grützner et al. 2017b) and there are few known slip rates on the active faults in the region (Campbell et al. 2013; Cording et al. 2014). It is likely that many more faults are unmapped or unrecognised as active (Grützner et al. 2017a).

While it appears from the GPS data that the KRF is creeping at the full slip-rate at present, the resolution of GPS is limited and as previously noted there is a regional velocity gradient that must also be accommodated by the faults of the region but cannot be attributed to any individual fault. By comparison, none of the other faults across the Tien Shan are well resolved in the GPS velocity field and yet they have accommodated several large (M8+) 
earthquakes in the past few hundred years (Figure1, e.g. Delvaux et al. 2001; Campbell et al. 2015; Abdrakhmatov et al. 2016). Thus, there may still be a degree of strain accumulation below the resolution limit of GPS, which could result in earthquakes. In addition, faults such as the Longitudinal Valley Fault have been shown to sustain earthquakes which nucleate in non-creeping velocity-weakening regions but propagate into velocity strengthening regions that deform primarily by creep (e.g. Thomas et al. 2014).

The greater rangefront of the Terskey Range is almost $600 \mathrm{~km}$ in length. It is unclear how far along this structure ruptures could propagate, though the section we primarily focus on in this study is $\sim 40 \mathrm{~km}$ without significant stepovers, suggesting a lower bound. If multiple segments can rupture together, however, we could expect large magnitude events. The evidence suggests that creep is accommodating a large fraction of the fault slip rate at present, which may be the long term mechanism for slip on this fault, but palaeoseismic excavation is required to ascertain whether the fault can sustain earthquakes. The majority of the primary scarps observed along the Karkara rangefront are very large to be attributable to single earthquake events - most terraces are uplifted by $>10 \mathrm{~m}$. The only exceptions are the river knick point at Rc1 with a relatively diffuse deflection of $2.5 \pm 0.5 \mathrm{~m}$ (\$2.1) and a terrace offset by $4.8 \pm 0.6 \mathrm{~m}$ at Rc3 (\$2.2). In most catchments (Rc1-3) we map multiple small secondary scarps south of the main fault trace with offsets of 1-2 m; these are consistent with hangingwall accommodation structures but it is unclear whether they are formed seismically.

At Rc3, the small scarp of $\sim 5 \mathrm{~m}$ and the numerous secondary scarps warrant further field investigation. The secondary scarps in particular present targets for palaeoseismology, as they may allow development of an earthquake record on a rangefront where the primary scarps are generally too large for trenching.

It is important to note that the GPS velocities of Zubovich et al. (2010) give exceptionally dense coverage and the duration of the campaigns has resulted in small errors there are few surveys of equivalent quality elsewhere. It is therefore quite possible that other intracontinental faults such as the KRF are creeping, but we are unable to resolve them with present geodetic data. Further work is needed along the KRF to further characterise 
the spatial extent and temporal evolution of the observed fault creep - it offers a unique opportunity to probe the frictional behaviour of a mature fault in an intracontinental setting.

\section{CONCLUSIONS}

We estimate a Late Quaternary slip rate on the Karkara Rangefront Fault of $3.5_{-0.4}^{+1.7} \mathrm{~mm} / \mathrm{yr}$ and a minimum uplift rate of $0.8 \mathrm{~mm} / \mathrm{yr}$ (though possibly as large as $1.8 \mathrm{~mm} / \mathrm{yr}$ ) at the core of the Kegen Basin Fold. Based on a conservative estimate of a steeply dipping basement fault, we estimate a minimum equivalent shortening rate of $1.1-3.3 \mathrm{~mm} / \mathrm{yr}$ across the rangefront. This is the fastest known fault slip-rate in the northern Tien Shan, but elastic halfspace modelling of the regional GPS shows that at present this is mostly accommodated by creep, suggesting that there is minimal strain accumulation at present within GPS resolution. We attribute the velocity strengthening properties of the fault necessary for creep to the mature nature of the Main Terskey Front.

Major earthquakes (M8+) have occurred in the past two centuries on other faults in the region that are completely unresolved in the regional GPS velocity field, so this fault may still be capable of earthquakes - further palaeoseismic investigation is necessary. This study also highlights the need for dense regional GPS surveys to identify creep - there may be many creeping faults unidentified due to the sparsity of GPS networks in intra-plate regions.

\section{ACKNOWLEDGMENTS}

This work was supported by funding from the UK Natural Environment Research Council (NERC) through the Looking Inside the Continents (LiCS) project (NE/K011006/1), the Earthquake without Frontiers (EwF) project (EwF_NE/J02001X/1_1), and the Centre for the Observation and Modelling of Earthquakes, Volcanoes and Tectonics (COMET) project (COME30001, http://comet.nerc.ac.uk). RTW also acknowledges support from the Royal Society. Many of the figures were made using the public domain software Generic Mapping Tools (Wessel \& Smith 1998). Analysis and visualisation of the DEMs and elevation pointclouds was performed using the KeckCaves virtual reality software suite. 


\section{REFERENCES}

Abdrakhmatov, K., Weldon, R. J., Thompson, S. C., Burbank, D. W., Rubin, C., Miller, M., \& Molnar, P., 2001. Onset, style and current rate of shortening in the central Tien Shan, Kyrgyz Republic, Russian Geology and Geophysics, 42(10), 1585-1609.

Abdrakhmatov, K., Walker, R., Campbell, G., Carr, A., Elliott, A., Hillemann, C., Hollingsworth, J., Landgraf, A., Mackenzie, D., Mukambayev, A., Rizza, M., \& Sloan, R., 2016. Multi-segment rupture in the July 11th 1889 Chilik earthquake (Mw 8.0-8.3), Kazakh Tien Shan, interpreted from remote-sensing, field survey, and palaeoseismic trenching, Journal of Geophysical Research: Solid Earth.

Abdrakhmatov, K. E., Djanuzakov, K. D., \& Delvaux, D., 2002. Active Tectonics and Seismic Hazard of the Issyk-Kul Basin in the Kyrgyz Tian-Shan, in Lake Issyk-Kul: Its Natural Environment, pp. 147-160, Springer Netherlands, Dordrecht.

Abdrakhmatov, K. Y., Aldazhanov, S. A., Hager;, B. H., Hamburger, M. W., Herring, T. A., Kalabaev, K. B., Makarov, V. I., \& Molnar, P., 1996. Relatively recent construction of the Tien Shan inferred from GPS measurements of present-day crustal deformation rates, Letters to Nature, 384.

Arrowsmith, J. R. \& Strecker, M. R., 1999. Seismotectonic range-front segmentation and mountain-belt growth in the Pamir-Alai region , Kyrgyzstan ( India-Eurasia collision zone ), Geological Society of America, 111(11), 1665-1683.

Arrowsmith, J. R., Crosby, C. J., Korzhenkov, A. M., Mamyrov, E., Povolotskaya, I., Guralnik, B., \& Landgraf, A., 2016. Surface rupture of the 1911 Kebin (ChonKemin) earthquake, Northern Tien Shan, Kyrgyzstan, Geological Society, London, Special Publications.

Avouac, J.-P., 1993. Analysis of scarp profiles: Evaluation of errors in morphologic dating, Journal of Geophysical Research, 98(B4), 6745.

Avouac, J.-P., 2015. From Geodetic Imaging of Seismic and Aseismic Fault Slip to Dynamic Modeling of the Seismic Cycle, Annual Review of Earth and Planetary Sciences, 43(1), 233271.

Avouac, J.-P. \& Tapponnier, P., 1993. Kinematic model of active deformation in central Asia, Geophysical Research Letters, 20(10), 895-898.

Bronk Ramsey, C., 2009. Bayesian Analysis of Radiocarbon Dates, Radiocarbon, 51(1), 337-360. Bullen, M. \& Burbank, D., 2001. Late Cenozoic tectonic evolution of the northwestern Tien Shan: New age estimates for the initiation of mountain building, Geological Society of America Bulletin, 113(12), 1544-1559.

Burbank, McLean, Bullen, Abdrakhmatov, \& Miller, 1999. Partitioning of intermontane basins by thrust-related folding, Tien Shan, Kyrgyzstan, Basin Research, 11(1), 75-92. 
Burbank, D. W. \& Anderson, R. S., 2011. Tectonic Geomorphology, John Wiley \& Sons, Ltd, Chichester, UK.

Burchfiel, B. C., Brown, E. T., Qidong, D., Xianyue, F., Jun, L., Molnar, P., Jianbang, S., Zhangming, W., \& Huichuan, Y., 1999. Crustal Shortening on the Margins of the Tien Shan, Xinjiang, China, International Geology Review, 41(January), 665-700.

Bürgmann, R. \& Dresen, G., 2008. Rheology of the Lower Crust and Upper Mantle: Evidence from Rock Mechanics, Geodesy, and Field Observations, Annual Review of Earth and Planetary Sciences, 36(1), 531-567.

Burtman, V. S., Skobelev, S. F., \& Molnar, P., 1996. Late Cenozoic slip on the Talas-Ferghana fault, the Tien Shan, central Asia, Geological Society of America Bulletin, 108(8), 1004-1021.

Campbell, G., 2015. Active Tectonics of the Tien Shan, Central Asia, Ph.D. thesis, University of Cambridge.

Campbell, G. E., Walker, R. T., Abdrakhmatov, K., Schwenninger, J., Jackson, J., Elliott, J. R., \& Copley, A., 2013. The Dzhungarian fault: Late Quaternary tectonics and slip rate of a major right-lateral strike-slip fault in the northern Tien Shan region, Journal of Geophysical Research: Solid Earth, 118, 5681-5698.

Campbell, G. E., Walker, R. T., Abdrakhmatov, K., Jackson, J., Elliott, J. R., Mackenzie, D., Middleton, T., \& Schwenninger, J.-L., 2015. Great earthquakes in low strain rate continental interiors: An example from SE Kazakhstan, Journal of Geophysical Research: Solid Earth, 120(8), $5507-5534$.

Carpenter, B. M., Marone, C., \& Saffer, D. M., 2011. Weakness of the San Andreas Fault revealed by samples from the active fault zone, Nature Geoscience, 4(4), 251-254.

Carretier, S., Ritz, J. F., Jackson, J., \& Bayasgalan, A., 2002. Morphological dating of cumulative reverse fault scarps: Examples from the Gurvan Bogd fault system, Mongolia, Geophysical Journal International, 148(2), 256-277.

Charreau, J., Avouac, J. P., Chen, Y., Dominguez, S., \& Gilder, S., 2008. Miocene to present kinematics of fault-bend folding across the Huerguosi anticline, northern Tianshan (China), derived from structural, seismic, and magnetostratigraphic data, Geology, 36(11), 871-874.

Chen, K. H. \& Bürgmann, R., 2017. Creeping faults: Good news, bad news?, Reviews of Geophysics, 55(2), 282-286.

Chester, F. M., Evans, J. P., \& Biegel, R. L., 1993. Internal structure and weakening mechanisms of the San Andreas Fault, Journal of Geophysical Research, 98(B1), 771.

Cohn, B. S. N., Allen, C. R., Oilman, R., \& Goulty, N. R., 1982. Preearthquake and postearthquake creep on the imperial fault and the brawley fault zone, in The Imperial Valley, California, earthquake of October 15, 1979. Geological Survey professional paper. No.1254, pp. 161-167, 
United States Geological Survey, Washington, DC.

Copley, A. \& Jolivet, R., 2016. Fault rheology in an aseismic fold-thrust belt (Shahdad, eastern Iran), Journal of Geophysical Research: Solid Earth, 121(1), 412-431.

Cording, A., Hetzel, R., Kober, M., \& Kley, J., 2014. 10Be exposure dating of river terraces at the southern mountain front of the Dzungarian Alatau (SE Kazakhstan) reveals rate of thrust faulting over the past $400 \mathrm{ka}$, Quaternary Research, 81(1), 168-178.

Delvaux, D., Abdrakhmatov, K., Lemzin, I., \& Strom, A., 2001. Landslides and surface breaks af the Ms 8.2 Kemin earthquake (Kyrgyzstan), Russian Geology and Geophysics, 42(10), 15831592.

Deng, Q., Zhang, P., Ran, Y., Yang, X., Min, W., \& Chu, Q., 2003. Basic characteristics of active tectonics of China, Science in China (Series D), 46(4), 356-372.

Deng, Q., Ran, Y., Yang, X., Min, W., \& Chu, Q., 2004. Map of Active Tectonics in China (in Chinese).

England, P. \& Molnar, P., 2015. Rheology of the lithosphere beneath the central and western Tien Shan, Journal of Geophysical Research: Solid Earth, 120(5), 3803-3823.

Gebhardt, A. C., Naudts, L., Mol, L. D., Klerkx, J., Abdrakhmatov, K., Sobel, E. R., \& De Batist, M., 2017. High-amplitude lake-level changes in tectonically active Lake Issyk-Kul ( Kyrgyzstan ) revealed by high-resolution seismic reflection data, Climate of the Past, 13, 73-92.

Glorie, S., De Grave, J., Buslov, M. M., Zhimulev, F. I., Stockli, D. F., Batalev, V. Y., Izmer, A., Van den haute, P., Vanhaecke, F., \& Elburg, M. A., 2011. Tectonic history of the Kyrgyz South Tien Shan (Atbashi-Inylchek) suture zone: The role of inherited structures during deformationpropagation, Tectonics, 30(6).

Goode, J. K., Burbank, D. W., \& Bookhagen, B., 2011. Basin width control of faulting in the Naryn Basin, south-central Kyrgyzstan, Tectonics, 30(6).

Goode, J. K., Burbank, D. W., \& Ormukov, C., 2014. Pliocene-Pleistocene initiation, style, and sequencing of deformation in the central Tien Shan, Tectonics, 33(4), 464-484.

Grützner, C., Carson, E., Walker, R., Rhodes, E., Mukambayev, A., Mackenzie, D., Elliott, J., Campbell, G., \& Abdrakhmatov, K., 2017a. Assessing the activity of faults in continental interiors: Palaeoseismic insights from SE Kazakhstan, Earth and Planetary Science Letters, 459, 93-104.

Grützner, C., Walker, R. T., Abdrakhmatov, K. E., Mukambaev, A., Elliott, A. J., \& Elliott, J. R., 2017b. Active tectonics around Almaty and along the Zailisky Alatau rangefront, Tectonics (In Press).

Harris, R. A., 2017. Large earthquakes and creeping faults, Reviews of Geophysics, 55(1), 169-198.

Hendrix, M. S., Graham, S. A., Carroll, A. R., Sobel, E. R., McKnight, C. L., Schulein, B. J., 
\& Wang, Z., 1992. Sedimentary record and climatic implications of recurrent deformation in the Tian Shan: Evidence from Mesozoic strata of the north Tarim, south Junggar, and Turpan basins, northwest China, Geological Society of America Bulletin, 104(1), 53-79.

Holt, W. E., Kreemer, C., Haines, a. J., Estey, L., Meertens, C., Blewitt, G., \& Lavallée, D., 2005. Project helps constrain continental dynamics and seismic hazards, Eos, Transactions American Geophysical Union, 86(41), 383.

Hubert-Ferrari, A., 2005. Irregular earthquake cycle along the southern Tianshan front, Aksu area, China, Journal of Geophysical Research, 110(B6), B06402.

Jolivet, R., Lasserre, C., Doin, M. P., Guillaso, S., Peltzer, G., Dailu, R., Sun, J., Shen, Z. K., \& Xu, X., 2012. Shallow creep on the Haiyuan fault (Gansu, China) revealed by SAR interferometry, Journal of Geophysical Research: Solid Earth, 117(6), 1-18.

Kaneko, Y., Fialko, Y., Sandwell, D. T., Tong, X., \& Furuya, M., 2012. Interseismic deformation and creep along the central section of the North Anatolian fault (Turkey): InSAR observations and implications for rate-and-state friction properties, Journal of Geophysical Research, 118, $1-15$.

Landgraf, A., Dzhumabaeva, A., Abdrakhmatov, K. E., Strecker, M. R., Macaulay, E. A., Arrowsmith, J. R., Sudhaus, H., Preusser, F., Rugel, G., \& Merchel, S., 2016. Repeated large-magnitude earthquakes in a tectonically active, low-strain continental interior: the northern Tien Shan, Kyrgyzstan, Journal of Geophysical Research: Solid Earth, pp. 1-23.

Le Béon, M., Suppe, J., Jaiswal, M. K., Chen, Y.-G., \& Ustaszewski, M. E., 2014. Deciphering cumulative fault slip vectors from fold scarps: Relationships between long-term and coseismic deformations in central Western Taiwan, Journal of Geophysical Research: Solid Earth, 119(7), 5943-5978.

Lienkaemper, J. J., Galehouse, J. S., \& Simpson, R. W., 2001. Long-term monitoring of creep rate along the Hayward fault and evidence for a lasting creep response to 1989 Loma Prieta earthquake, Geophysical Research Letters, 28(11), 2265-2268.

Macaulay, E. A., Sobel, E. R., Mikolaichuk, A., Landgraf, A., Kohn, B., \& Stuart, F., 2013. Thermochronologic insight into late Cenozoic deformation in the basement-cored Terskey Range, Kyrgyz Tien Shan, Tectonics, 32(3), 487-500.

Macaulay, E. A., Sobel, E. R., Mikolaichuk, A., Kohn, B., \& Stuart, F. M., 2014. Cenozoic deformation and exhumation history of the Central Kyrgyz Tien Shan, Tectonics, 33(2), 135165.

Mackenzie, D., Abdrakhmatov, K., Campbell, G., Grützner, C., Carson, E., \& Moldobaeb, A., 2015. A transect of quaternary geological slip rates in the Kazakh Tien Shan, in 6th International INQUA Meeting on Paleoseismology, Active Tectonics and Archaeoseismology, no. April, pp. 
267-270.

Marone, C., 1998. Laboratory-Derived Friction Laws and Their Application To Seismic Faulting, Annual Review of Earth and Planetary Sciences, 26(1), 643-696.

Oskin, M. E. \& Burbank, D., 2007. Transient landscape evolution of basement-cored uplifts: Example of the Kyrgyz Range, Tian Shan, Journal of Geophysical Research, 112(F03S03).

Pigati, J. S., Rech, J. A., \& Nekola, J. C., 2010. Radiocarbon dating of small terrestrial gastropod shells in North America, Quaternary Geochronology, 5(5), 519-532.

Reid, H. F., 1910. The mechanics of the earthquake, The California Earthquake of April 18, 1906:, Report of the State Earthquake Investigation Commission, 2(87).

Reilinger, R. E., Ergintav, S., Burgmann, R., McClusky, S., Lenk, O., Barka, A., Gurkan, O., Hearn, L., Feigl, K. L., Cakmak, R., Aktug, B., Ozener, H., \& Toksoz, M. N., 2000. Coseismic and Postseismic Fault Slip for the 17 August 1999, M = 7.5, Izmit, Turkey Earthquake, Science, 289(5484), 1519-1524.

Reimer, P., 2013. IntCal13 and Marine13 Radiocarbon Age Calibration Curves 0-50,000 Years cal BP, Radiocarbon, 55(4), 1869-1887.

Segall, P., 2010. Earthquake and volcano deformation, Princeton University Press.

Selander, J., Oskin, M., Ormukov, C., \& Abdrakhmatov, K., 2012. Inherited strike-slip faults as an origin for basement-cored uplifts: Example of the Kungey and Zailiskey ranges, northern Tian Shan, Tectonics, 31(4).

Smith, S. W. \& Wyss, M., 1968. Displacement on the San Andreas fault subsequent to the 1966 Parkfield earthquake, Bulletin of the Seismological Society of America, 58(6), 1955-1973.

Sobel, E. R., Oskin, M., Burbank, D., \& Mikolaichuk, A., 2006. Exhumation of basement-cored uplifts: Example of the Kyrgyz Range quantified with apatite fission track thermochronolgy, Tectonics, 25(2).

Steinbrugge, K. V., Zacher, E. G., Tocher, D., Whitten, C. A., \& Claire, C. N., 1960. Creep on the San Andreas Fault, Bulletin of the Seismological Society of America, 50(3), 389-396.

Takaku, J., Tadono, T., \& Tsutsui, K., 2014. Generation of High Resolution Global DSM from ALOS PRISM, ISPRS - International Archives of the Photogrammetry, Remote Sensing and Spatial Information Sciences, XL-4(4), 243-248.

Tapponnier, P. \& Molnar, P., 1979. Active faulting and cenozoic tectonics of the Tien Shan, Mongolia, and Baykal Regions, Journal of Geophysical Research: Solid Earth, 84(B7), 34253459.

Thatcher, W., 1983. Nonlinear strain buildup and the earthquake cycle on the San Andreas Fault, Journal of Geophysical Research: Solid Earth, 88(B7), 5893-5902.

Thomas, M. Y., Avouac, J.-P., Champenois, J., Lee, J.-C., \& Kuo, L.-C., 2014. Spatiotemporal 
evolution of seismic and aseismic slip on the Longitudinal Valley Fault, Taiwan, Journal of Geophysical Research: Solid Earth, 119(6), 5114-5139.

Thompson, S. C., Weldon, R. J., Rubin, C. M., Abdrakhmatov, K., Molnar, P., \& Berger, G. W., 2002. Late Quaternary slip rates across the central Tien Shan, Kyrgyzstan, central Asia, Journal of Geophysical Research, 107(B9), 2203.

Titus, S. J., DeMets, C., \& Tikoff, B., 2006. Thirty-five-year creep rates for the creeping segment of the San Andreas fault and the effects of the 2004 Parkfield earthquake: Constraints from alignment arrays, continuous global positioning system, and creepmeters, Bulletin of the Seismological Society of America, 96(4 B), 250-268.

Tse, S. T. \& Rice, J. R., 1986. Crustal earthquake instability in relation to the depth variation of frictional slip properties, Journal of Geophysical Research, 91(B9), 9452-9472.

Wallace, R. E., 1977. Profiles and ages of young fault scarps, north-central Nevada, Geological Society of America Bulletin, 88(9), 1267.

Wessel, P. \& Smith, W. H. F., 1998. New, improved version of generic mapping tools released, Eos, Transactions American Geophysical Union, 79(47), 579-579.

Yin, A., Nie, S., Craig, P., Harrison, T. M., Ryerson, F. J., Xianglin, Q., \& Geng, Y., 1998. Late Cenozoic tectonic evolution of the southern Chinese Tian Shan, Tectonics, 17(1), 1-27.

Zubovich, A. V., Wang, X.-Q., Scherba, Y. G., Schelochkov, G. G., Reilinger, R., Reigber, C., Mosienko, O. I., Molnar, P., Michajljow, W., Makarov, V. I., Li, J., Kuzikov, S. I., Herring, T. A., Hamburger, M. W., Hager, B. H., Dang, Y.-M., Bragin, V. D., \& Beisenbaev, R. T., 2010. GPS velocity field for the Tien Shan and surrounding regions, Tectonics, 29(6). 

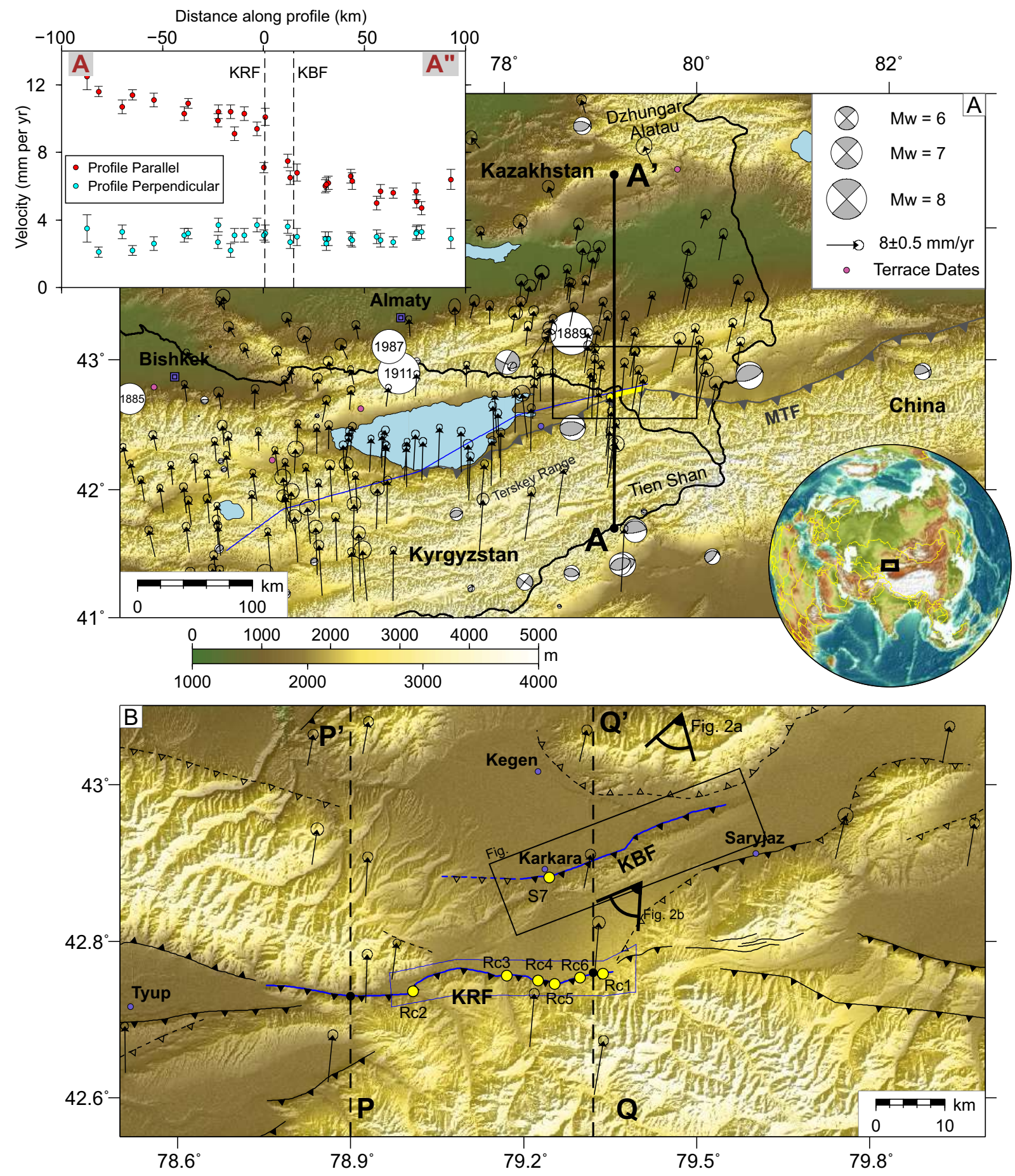

Figure 1. (top) An overview of the NE Tien Shan. Historic earthquakes of M>6 are shown as open circles, and focal mechanisms show modern instrumental earthquakes of $\mathrm{M}>6$ from the global centroid moment tensor (GCMT) catalogue. GPS velocity vectors are from Zubovich et al. (2010) and ellipses indicate the $95 \%$ confidence interval. The blue line represents the discrete step in the northwards regional GPS velocities identified by England \& Molnar (2015). (inset) GPS velocity vectors over a swath width of $\pm 40 \mathrm{~km}$ projected on to the line $\mathrm{A}-\mathrm{A}$. Dashed line indicates the surface fault location. Error bars indicate the 95\% confidence interval. Modified after Mackenzie et al. (2015). (bottom) Inset showing the Karkara Rangefront (KRF), the Kegen Basin Fold (KBF), and the individual study sites Rc1-3. Blue outline shows the extents of the stereo Pléiades derived DEM. Profiles P-P' and Q-Q' are the two profiles taken through the regional GPS velocity field, modelled to estimate the fault creep rate (Figure 14). 


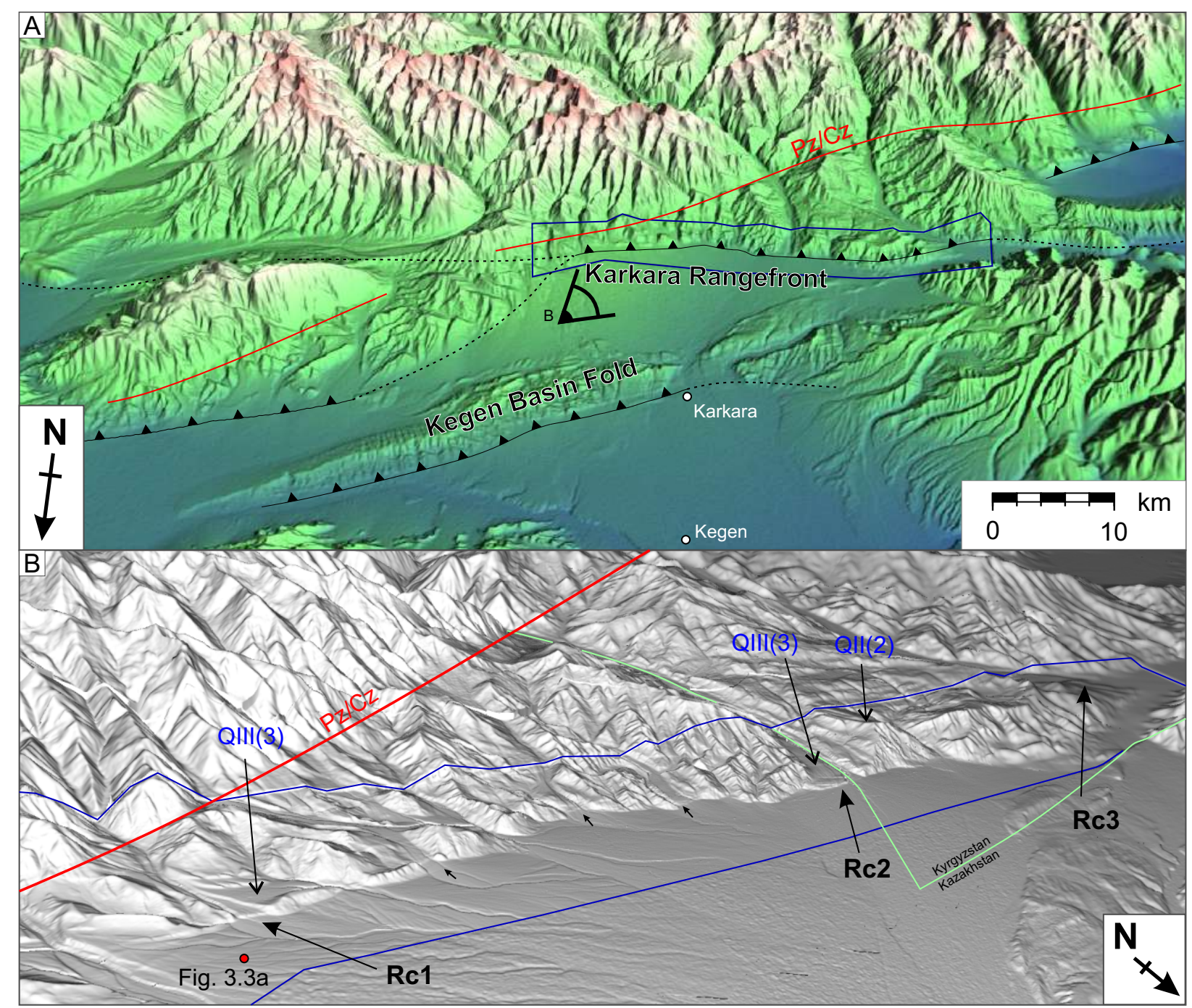

Figure 2. (a) Perspective view of the Terskey northern rangefront, showing the major structures studied here. Basemap elevation data from the SRTM 1-second dataset. 2x vertical exaggeration. Red line indicates the Palaeozoic-Cenozoic contact at the surface for the Karkara Rangefront. (b) Perspective view looking SW along the KRF, from the Pléiades derived DEM on top of the AW3D30 DEM (Takaku et al. 2014), showing the individual river catchments studied. Minor arrows indicate the catchments described in Supplement S2. Blue lines outline of the high resolution dataset. 


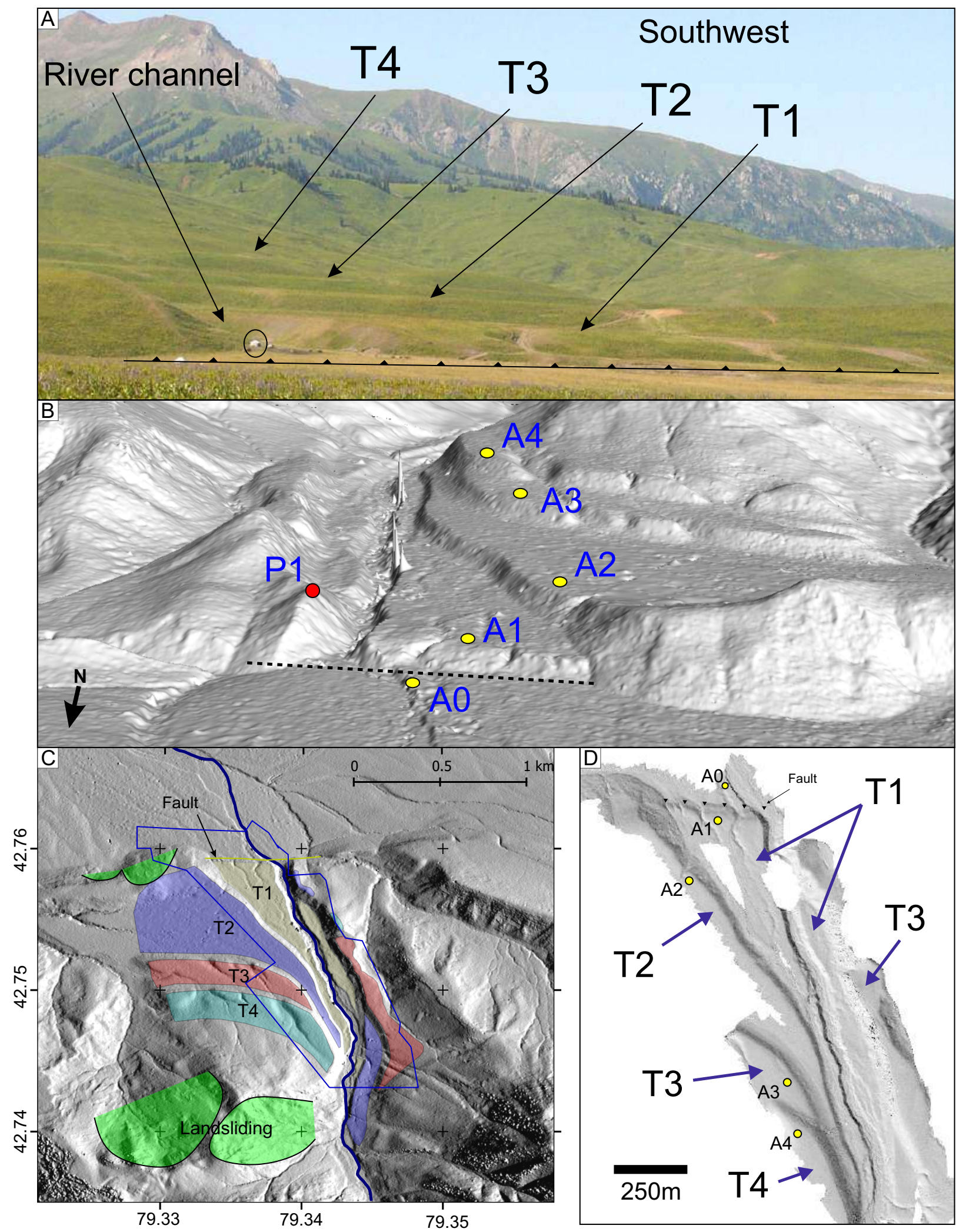

Figure 3. (a) Overview of the stepped terraces, T1-4, with the fault in the foreground, yurt circled for scale. (b) Perspective view looking south at the flight of terraces, based on shaded relief of the Pléiades $2 \mathrm{~m}$ DEM. Sampling sites are marked as yellow dots. Red dot marks location of photo in Figure 5. 2x vertical exaggeration. (c) Map of the terraces at Rc1. T1-4 shown as coloured polygons with colours consistent with the terraces shown in later figures. Green line marks the fault surface trace in the most recently abandoned terrace. Landslides shown as green polygons. Blue outline shows the extents of the SfM survey in (d). (d) Shaded relief of the $30 \mathrm{~cm}$ SfM DEM, with terraces and sampling locations labelled. 

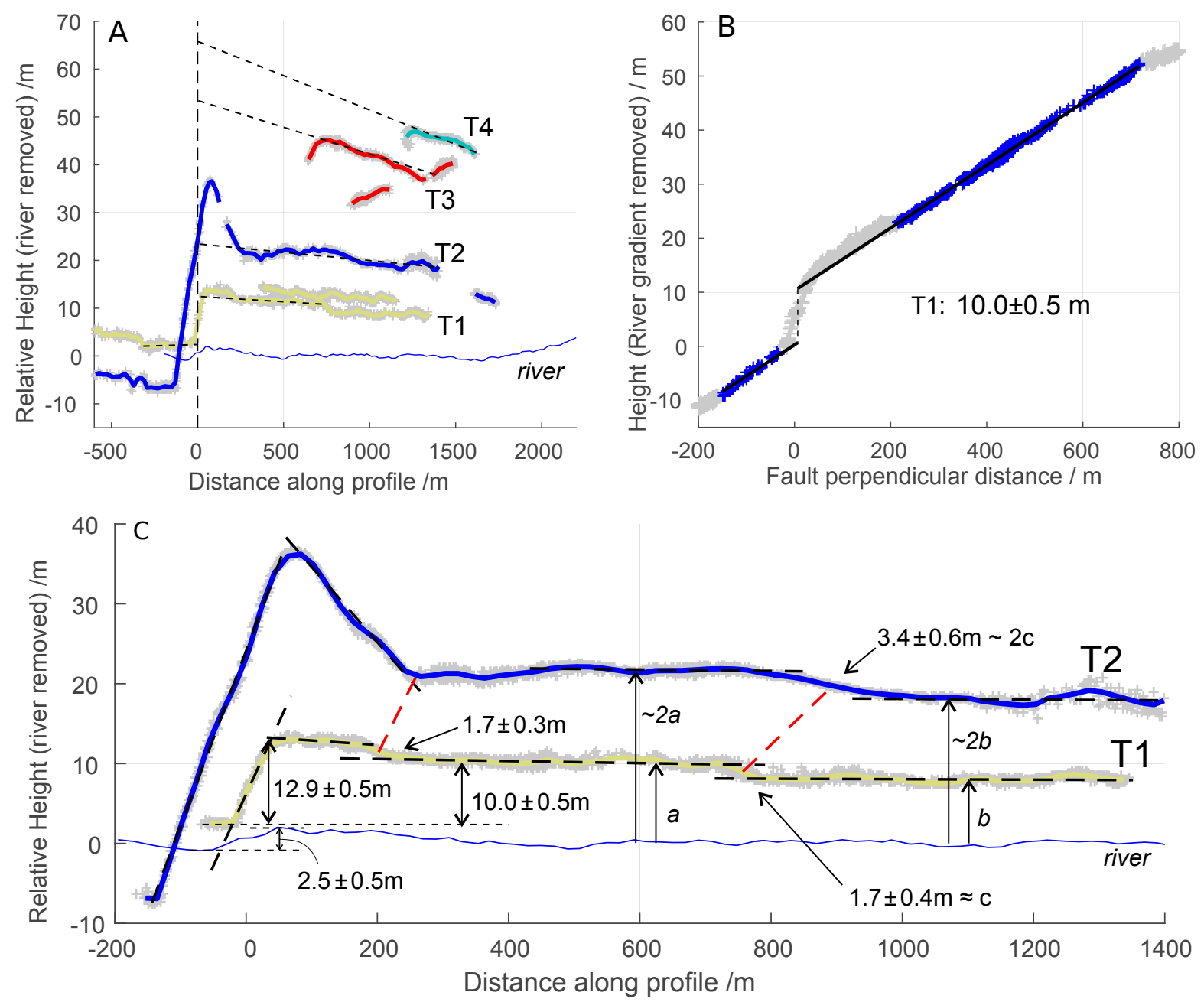

Figure 4. (a) Profiles along each of the identified river terraces orthogonal to local fault strike and with the $\mathrm{x}$-axis origin set at the fault. The present river gradient has been removed from all profiles (blue line shows the residual river). Colours correspond to the polygon colours in Figure 3 . (b) Profile across the most recent terrace T1 (without river gradient removed). Offset: $10.0 \pm 0.5 \mathrm{~m}$, though this is larger in the $\sim 200 \mathrm{~m}$ nearest the fault trace. (c) Zoomed section of terraces T1 and $\mathrm{T} 2$ in (a). Two steps in the T1 and T2 terrace surfaces are well correlated (dashed red lines), and approximate offsets shown. The steepening of the river gradient near the fault is visible, with an offset of $\sim 2.5 \mathrm{~m}$. 


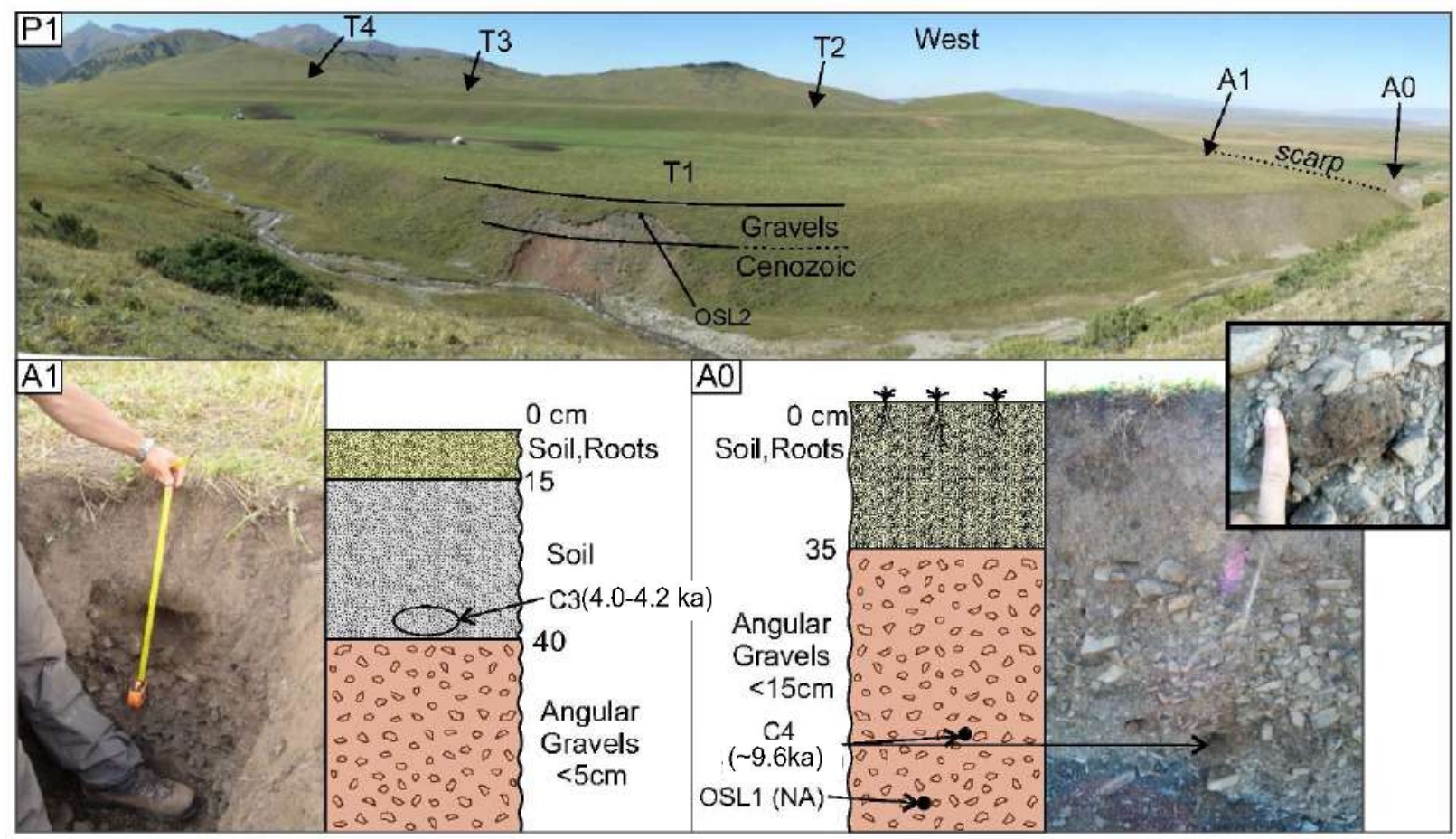

Figure 5. (top) Panorama looking across the T1 surface from the opposite side of the river (location in Figure 3). The contact between the red Neogene sediments and the terrace gravels is visible in the terrace riser in the foreground. (A1) Stratigraphy of the Pit in T1 in the hangingwall, $\sim 0.40 \mathrm{~cm}$ soil, overlying fluvial gravels. (A0) Stratigraphy of the stream cut exposure in the footwall deposits. $\sim 0.45 \mathrm{~m}$ Soil thickness, overlying fluvial gravels interspersed with occasional sand lenses. Locations of the radiocarbon and OSL/IRSL samples are shown. Radiocarbon ages are described fully in Table 1 . 


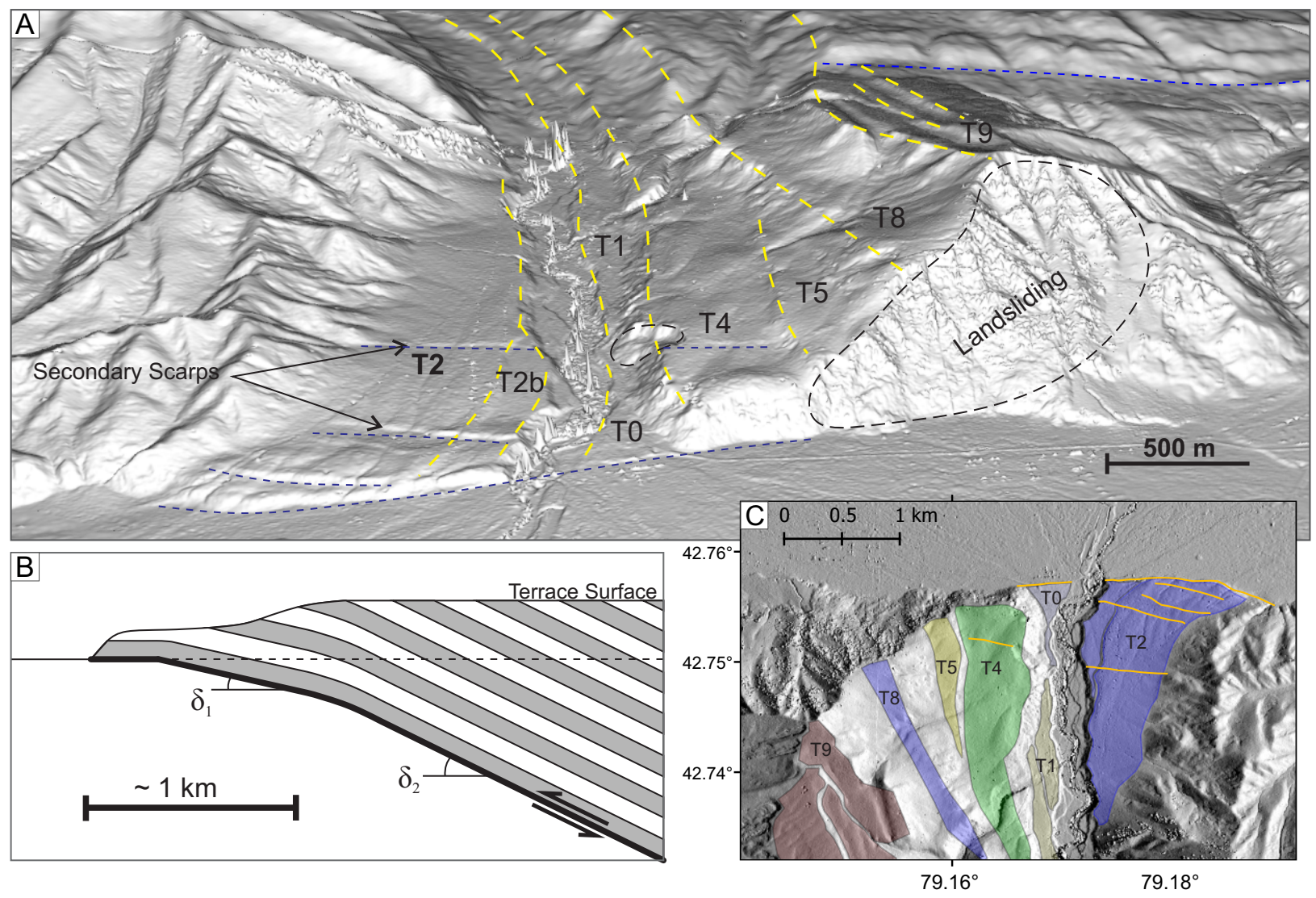

Figure 6. (a) Perspective view of the DEM at the border site at Rc2 (looking S, illuminated from viewpoint). The background low resolution DEM is from the AW3D30 dataset, in which the larger terraces are still visible. Terrace riser tops are highlighted with yellow dashed lines. Fault scarps are shown as blue dashed lines. (b) Hypothetical model of the shallow subsurface based on the terrace deformation (see Figure 7) with indicative horizontal scale included. The fault is likely to flatten into a detachment at depths greater than represented here, as inferred from southward-directed tilting of the terraces over distances of greater than $1 \mathrm{~km}$. (c) Map of the terraces observed at Rc2, on top of shaded relief from the Pléiades DEM (illuminated from the East). Terrace polygon colours are consistent with those correlated at the other catchments. 

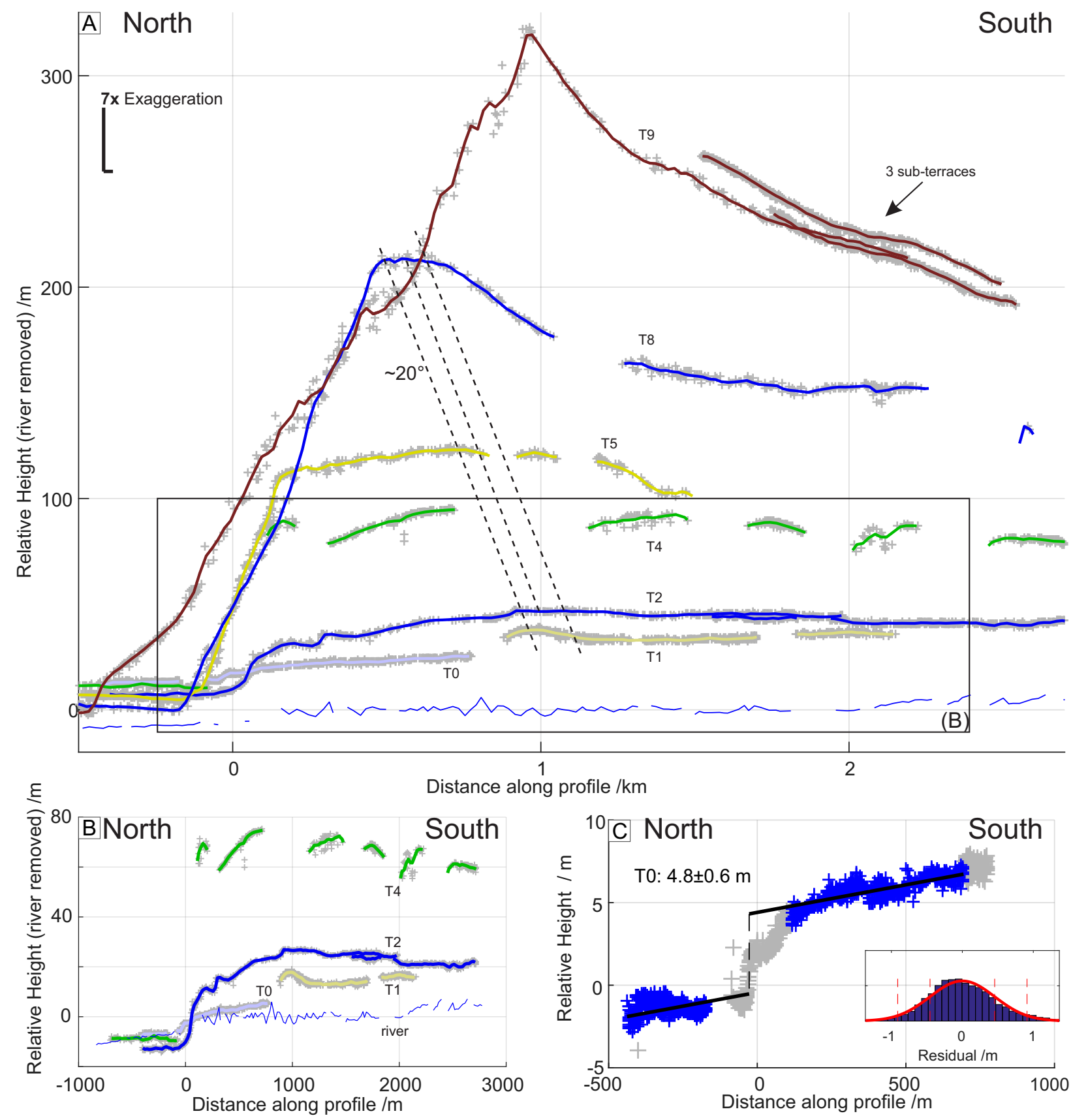

Figure 7. (a) Long profiles along all of the terraces, collapsed onto an azimuth of $80^{\circ}$. All of the terraces show an increase in displacement relative to modern river level towards the basin, suggesting the fault dip flattens upwards.(b) Profiles across the lowest four terraces at the Rc2 catchment show a broad warping. It is unclear whether T1 and T0 are the same terrace. (c) Profile across the unique low scarp (T0), measuring a vertical offset of $\sim 4.8 \mathrm{~m}$ at the fault trace (inset shows histogram of residuals). 

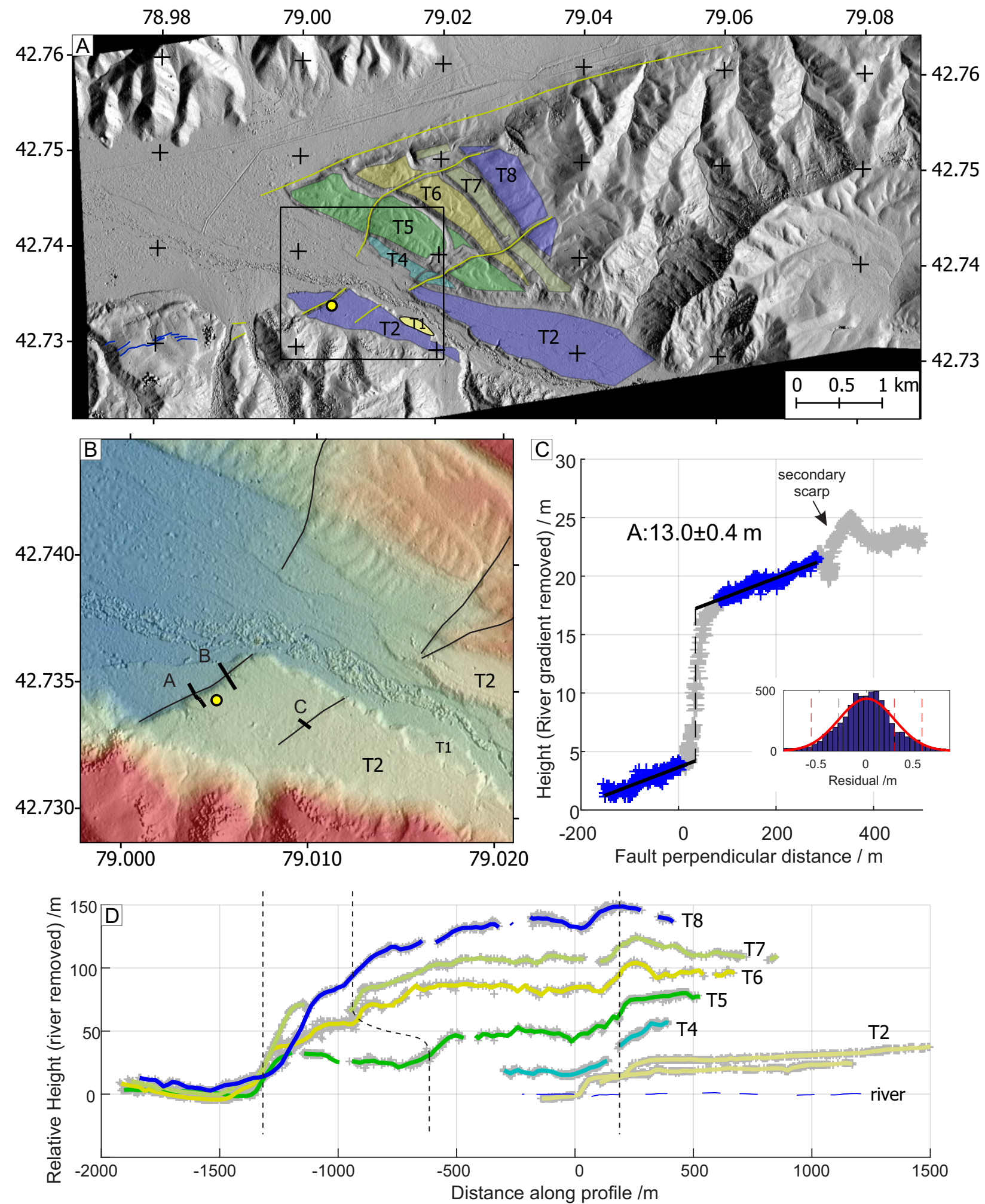

Figure 8. (a) Map of the Basharin site, highlighting the series of terraces observed. Labels correspond to the correlated terraces at other sites (\$2.2). (b) Zoom near the scarp, showing the location of the three shallow hammer seismic refraction/reflection lines across the scarps, and the sampling pit location. (c) A topographic profile across the scarp in the most recent displaced terrace (T1), in the vicinity of seismic reflection profiles A and B. The inset shows the histogram of residuals. (d) Long profiles through the flight of terraces collapsed onto an azimuth of $070^{\circ}$, show displacements of up to $150 \mathrm{~m}$ relative to the modern river channel; the older terraces mark fault displacement in several locations (dashed lines). The older terraces with greater maximum displacement show more displacement further north, while the more recent terrace only shows displacement on the southern fault strand. 


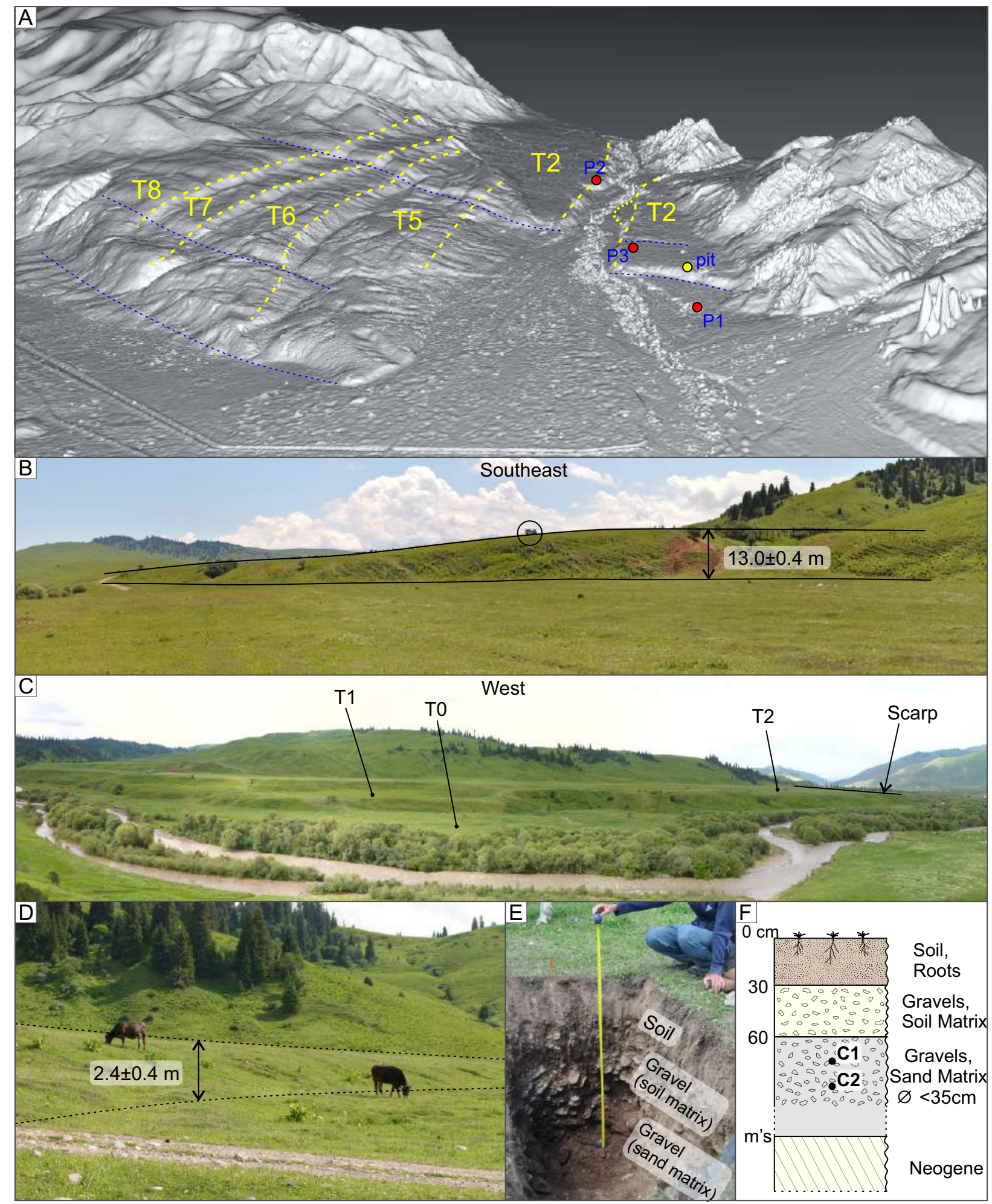

Figure 9. (a) Perspective view of the flight of terraces at Rc3. Note the tilting of the terraces away from the river channel. P1, P2 and P3 mark the locations of the photos in (b), (c) and (d) respectively. Blue dashed lines mark fault scarps. (b) Panoramic view (3 photos stitched in cylindrical projection) of the fault scarp in the T2 terrace surface, with an offset of $\sim 13 \mathrm{~m}$. Car for scale. (c) Panoramic view of the terraces on the western bank ( 5 photos, stitched in stereographic projection). (d) The smaller secondary scarp (cows for scale), $\sim 400 \mathrm{~m}$ from the main scarp in the terrace surface of T2 has an offset of $\sim 2.4 \mathrm{~m}$. (e) Sampling pit in the T2 surface. (f) Stratigraphy of the T2 terrace surface. Both radiocarbon samples came from within the gravels with a sand matrix. The presence of Neogene sediments at several metres depth is inferred from outcrops in the present river bed and the seismic reflection profile. 

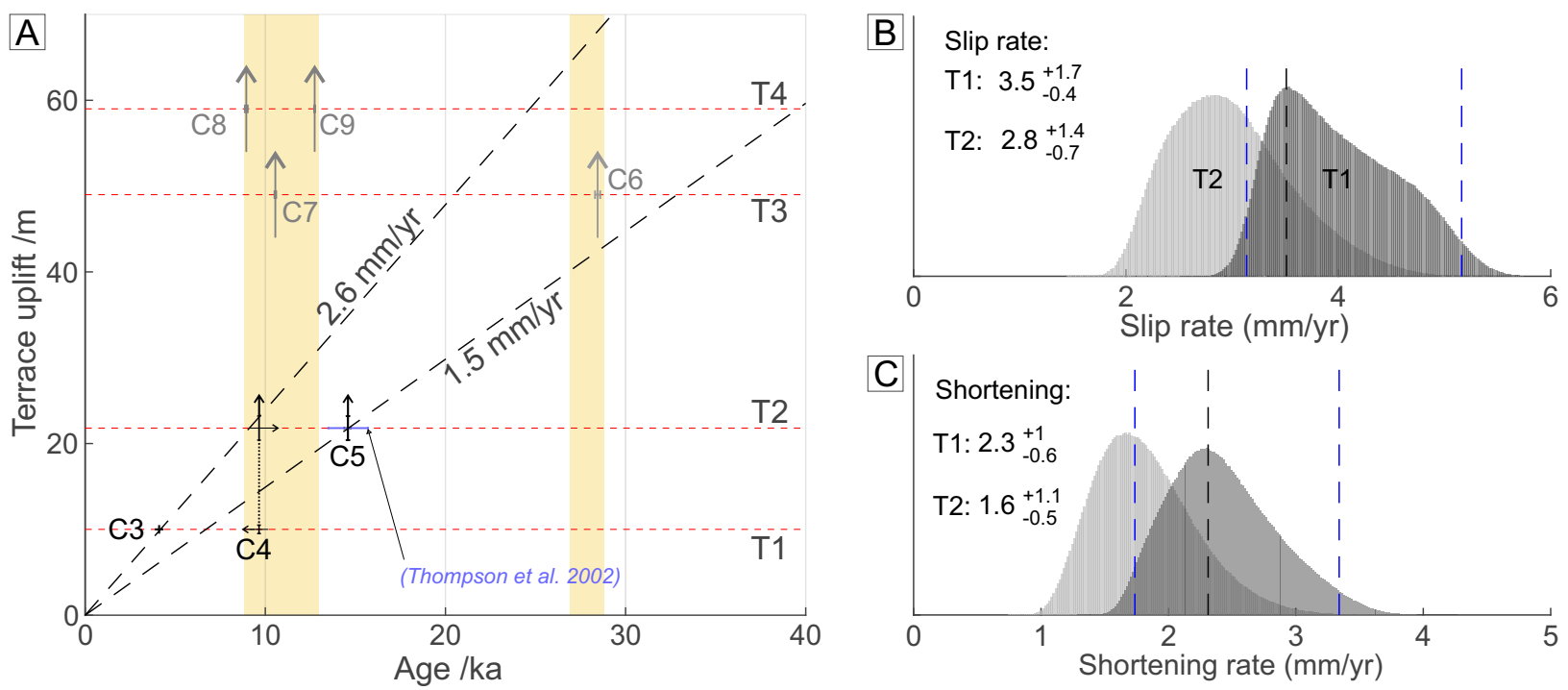

Figure 10. (a) Plot of uplift against age for the terraces at Rc1. Points in black represent those used to estimate uplift rates. Grey points represent anomalously young ages, possibly due to accelerated soil development or excessive groundwater in the post-LGM period. Yellow highlight indicates the two short periods that capture the majority of the dated samples. Horizontal dashed lines represent the estimated minimum terrace uplifts relative to the modern river level. (b-c) Monte-Carlo simulation generated PDFs for the shortening rate and slip rate based on the uplift rates for $\mathrm{T} 1$ and $\mathrm{T} 2$. 


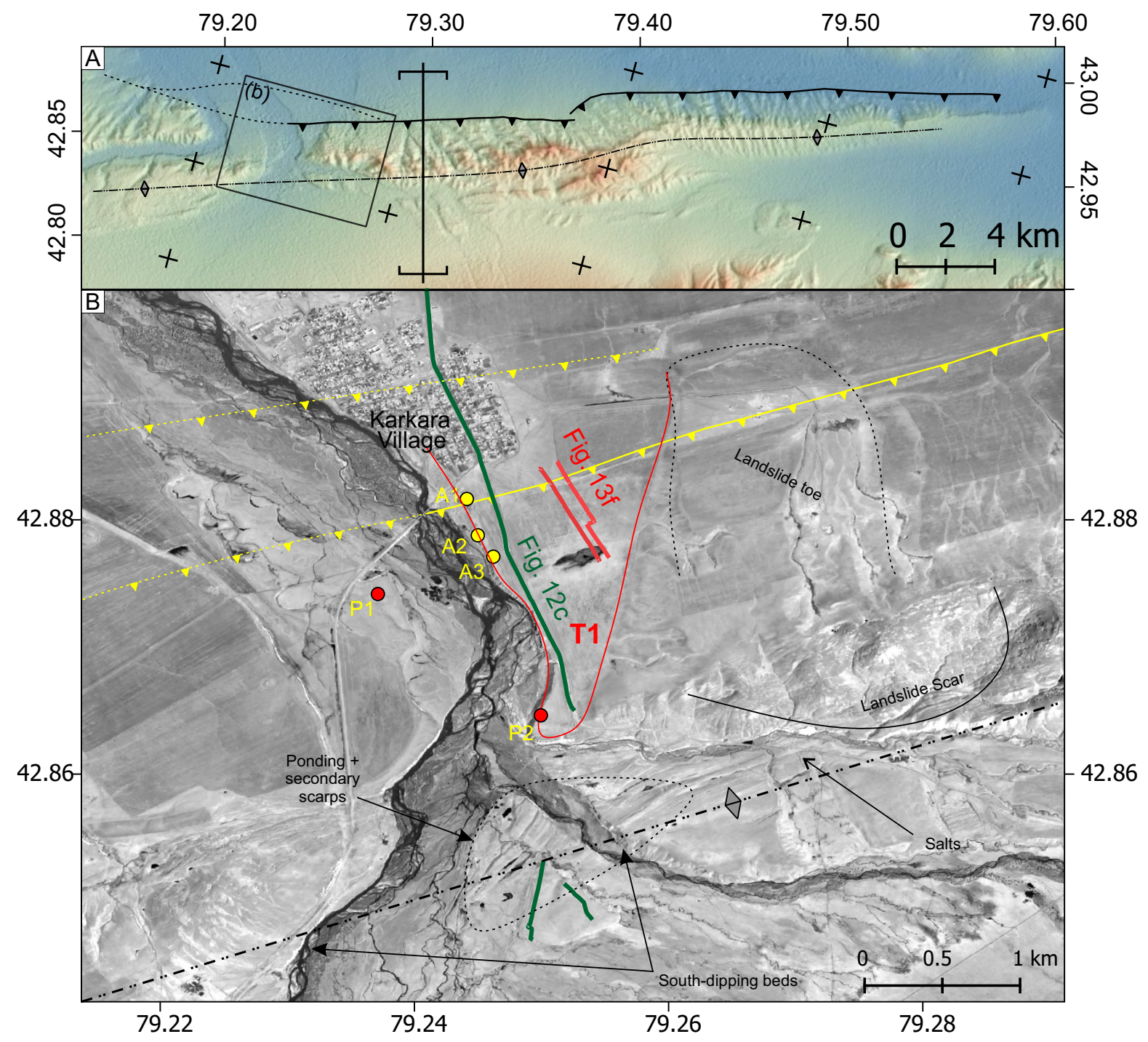

Figure 11. (a) Map of the Kegen Basin Fold, which runs approximately NE-SW across the Kegen Basin. The estimated fold axis is shown, along with the mapped fault at the surface along the northern edge of the fold. B-B' marks the location of the topography swath profile in Figure 12 (b) Map of site Q7, where the Karkara River cuts the Kegen fold. Basemap is $1 \mathrm{~m}$ resolution panchromatic Kompsat-2 imagery. Locations of the GPS profiles are shown as red and green lines. Sampling sites are shown as yellow dots, and the locations of the photos in Figures $12 \mathrm{a}, \mathrm{b}, 13 \mathrm{a}$, are shown as red dots. 

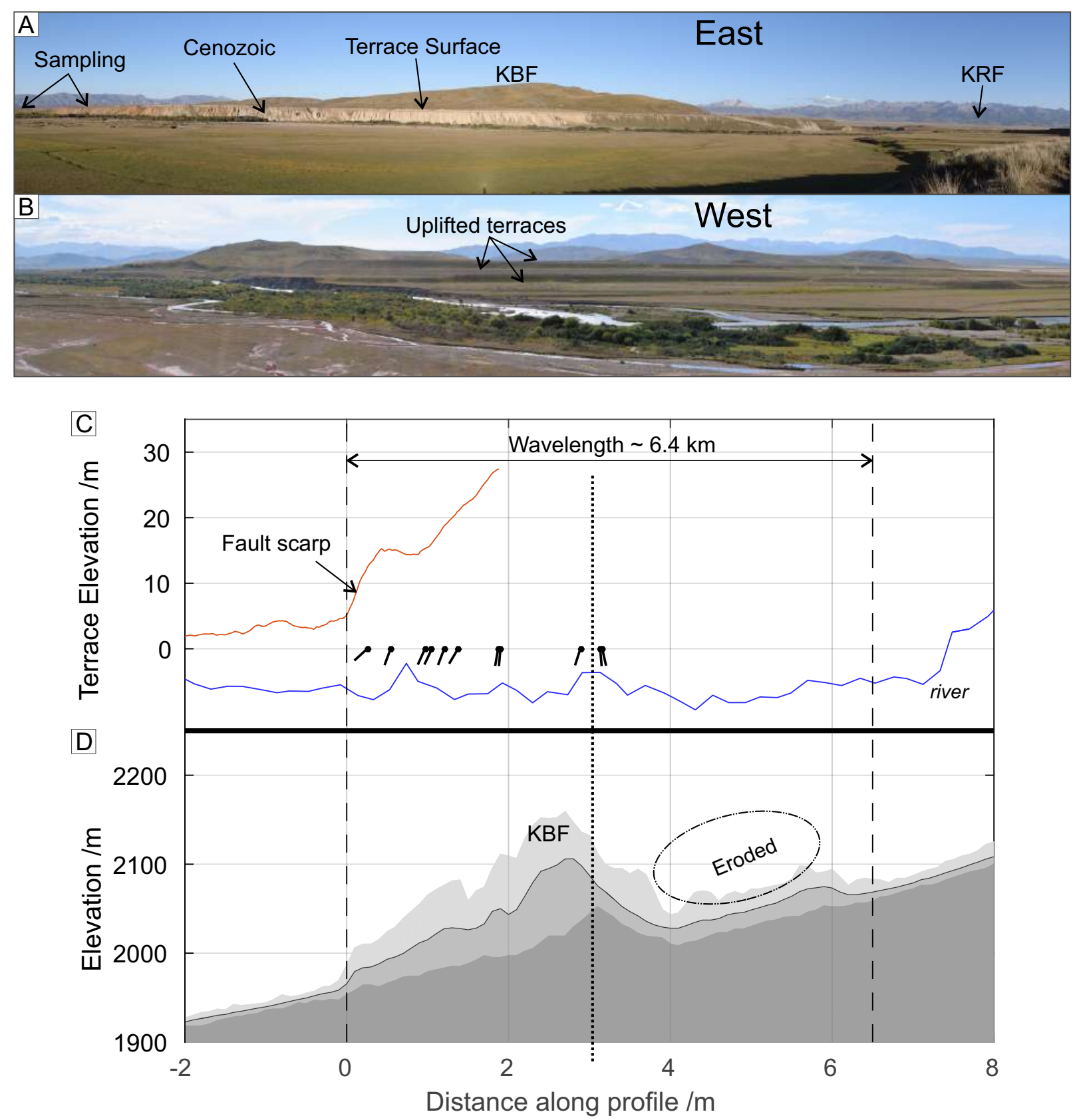

Figure 12. (a) Photograph looking east across the Karkara river to the long continuous terrace surface on the eastern side. The terrace consists of a thin gravel layer lying unconformably on steeply dipping Cenozoic sediments. Behind the terrace, the profile of the fold can be seen. (b) Photograph looking west across the Karkara river to the flight of terraces on the western side. (photo locations in Figure 11). (c) Long terrace profile with kinematic GPS along the terrace warped by folding is shown in red. The present river gradient, estimated from SRTM, has been removed from the profiles. The residuals to a linear fit to the present river channel over the wavelength from the fold is shown in blue. The apparent bedding dips are marked in black, showing a clear change from north dipping to south dipping at $\sim 3 \mathrm{~km}$ from the fault trace (markers not scaled to the vertical axis). (d) Cross section through the minimum, mean and maximum topography across the fold in the swath profile shown in Figure 11. 


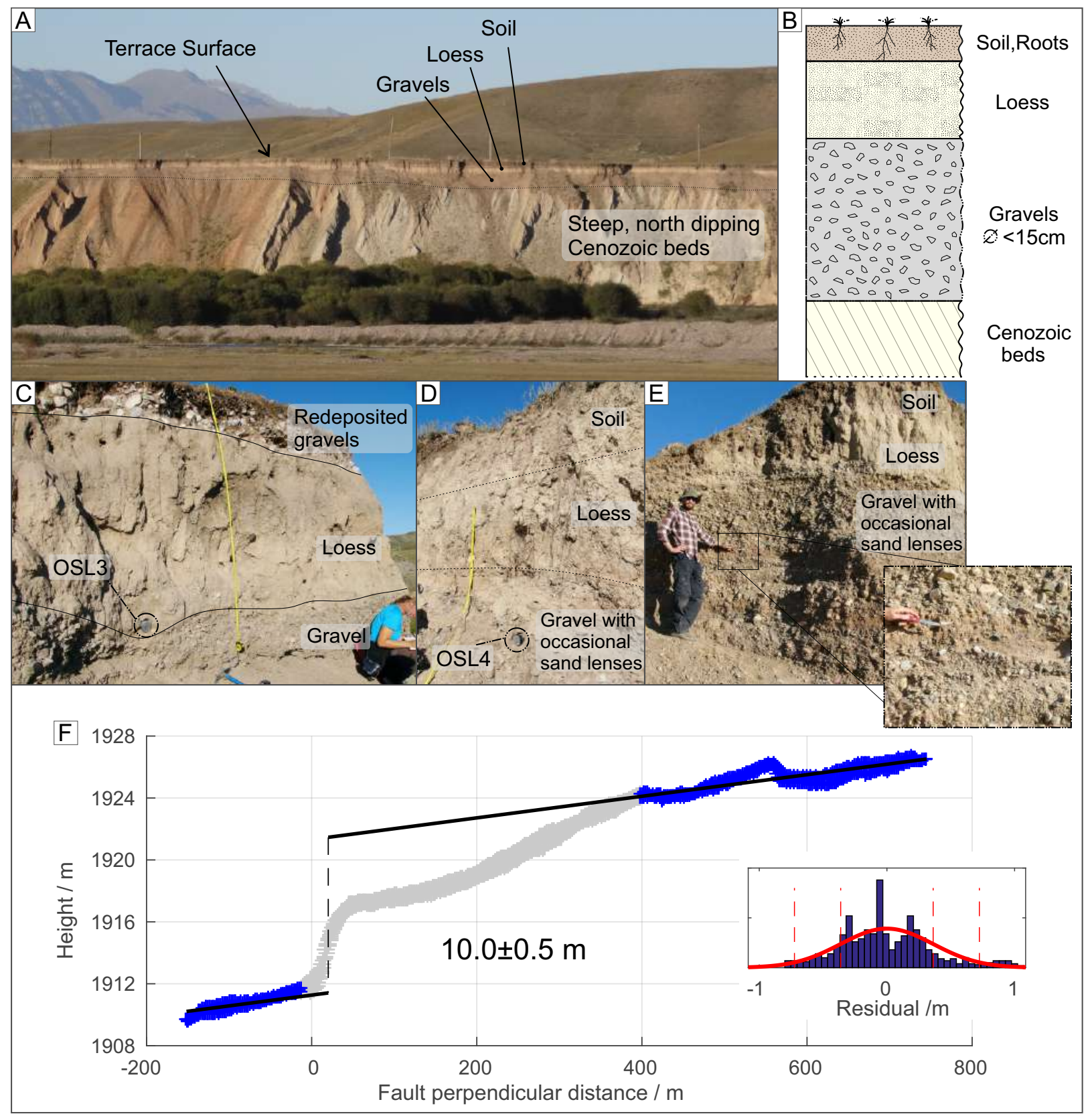

Figure 13. (a) View east across the river. Steeply north-dipping Cenozoic sediments are capped with terrace deposits. (b) Approximate profile of the terrace stratigraphy. A thin soil cap sits on top of a thick $(1-3 \mathrm{~m}$ ) loess layer. Beneath this, $\sim 1-5 \mathrm{~m}$ of gravels, lie unconformably on the the Cenozoic sediments. (c) Setting of sample OSL1. With an age of 15-17 ka (Tables 2- 3) we interpret this as being within post abandonment channel fill. (d) Sample OSL2, from a coarse sand lens within the terrace gravels. (e) Sample C10, amalgamated gastropod shell fragment sample from a shell containing lens of sand within the terrace gravels. Sample C11 was collected from a similar setting $\sim 500 \mathrm{~m}$ further south. (f) Two stacked kinematic GPS profiles across the fault scarp near the town of Karkara show an offset of $10.0 \pm 0.5 \mathrm{~m}$ in the terrace surface at the fault scarp. The inset shows a histogram of residuals to the linear fit. 

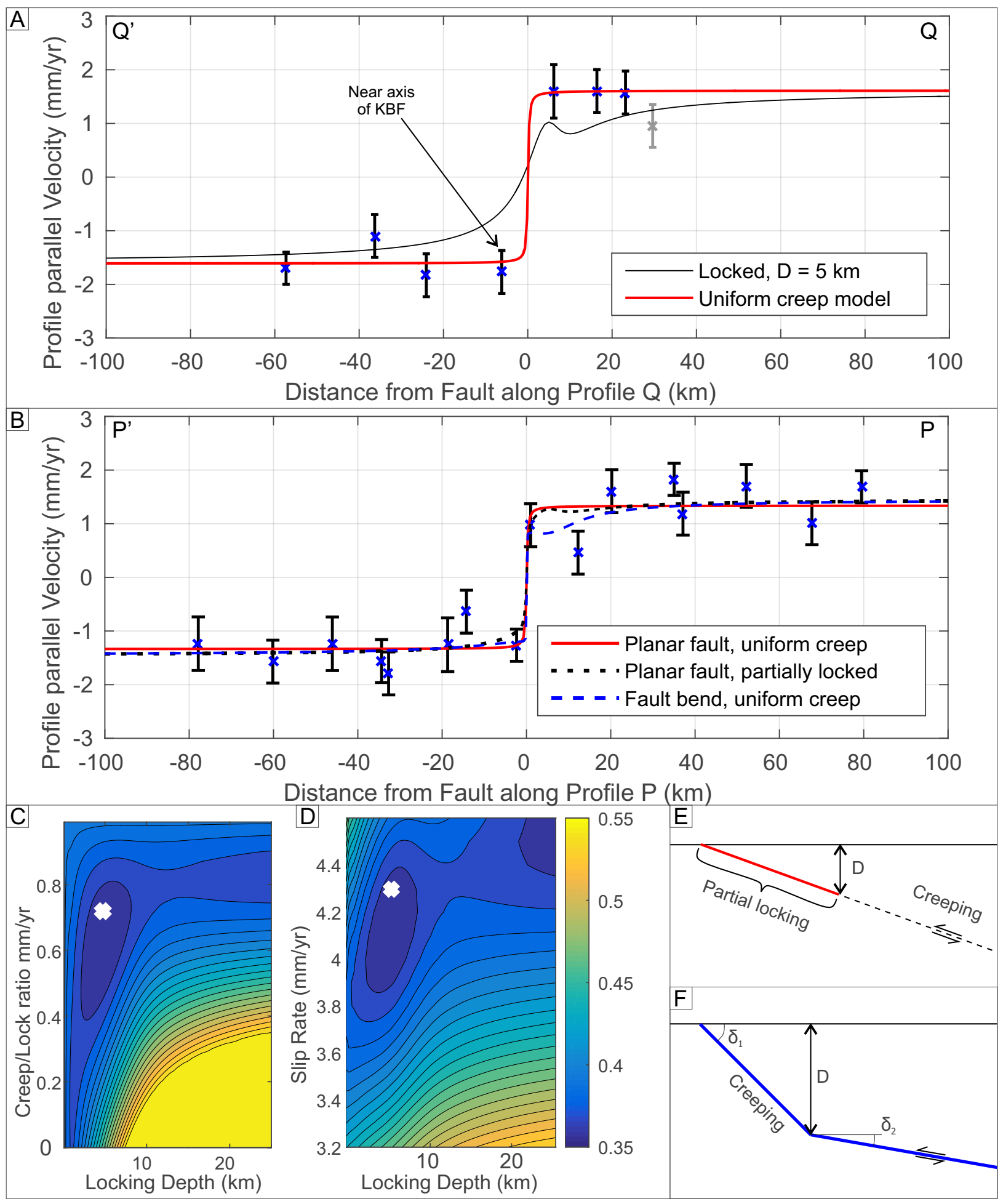

Figure 14. (a-b) Modelling of profiles $\mathrm{Q}$ and $\mathrm{P}$ through the regional GPS field of Zubovich et al. (2010), perpendicular to the KRF. Errorbars indicate the $95 \%$ confidence interval. Profile Q is well fit by a single planar fault creeping right to the surface, whereas profile $\mathrm{P}$ is better fit either by a partially locked upper segment, or a change in geometry at $\sim 5-10 \mathrm{~km}$ depth. Map locations of stations shown in Figure 1. (c) Rms well for the locking ratio with locking depth in the partially locked model for profile P. (d) Rms well for the slip-rate with locking depth in the partially locked model for profile P. (e-f) Schematic diagrams of the partially locked model and flat-ramp model giving the fits in (b). 


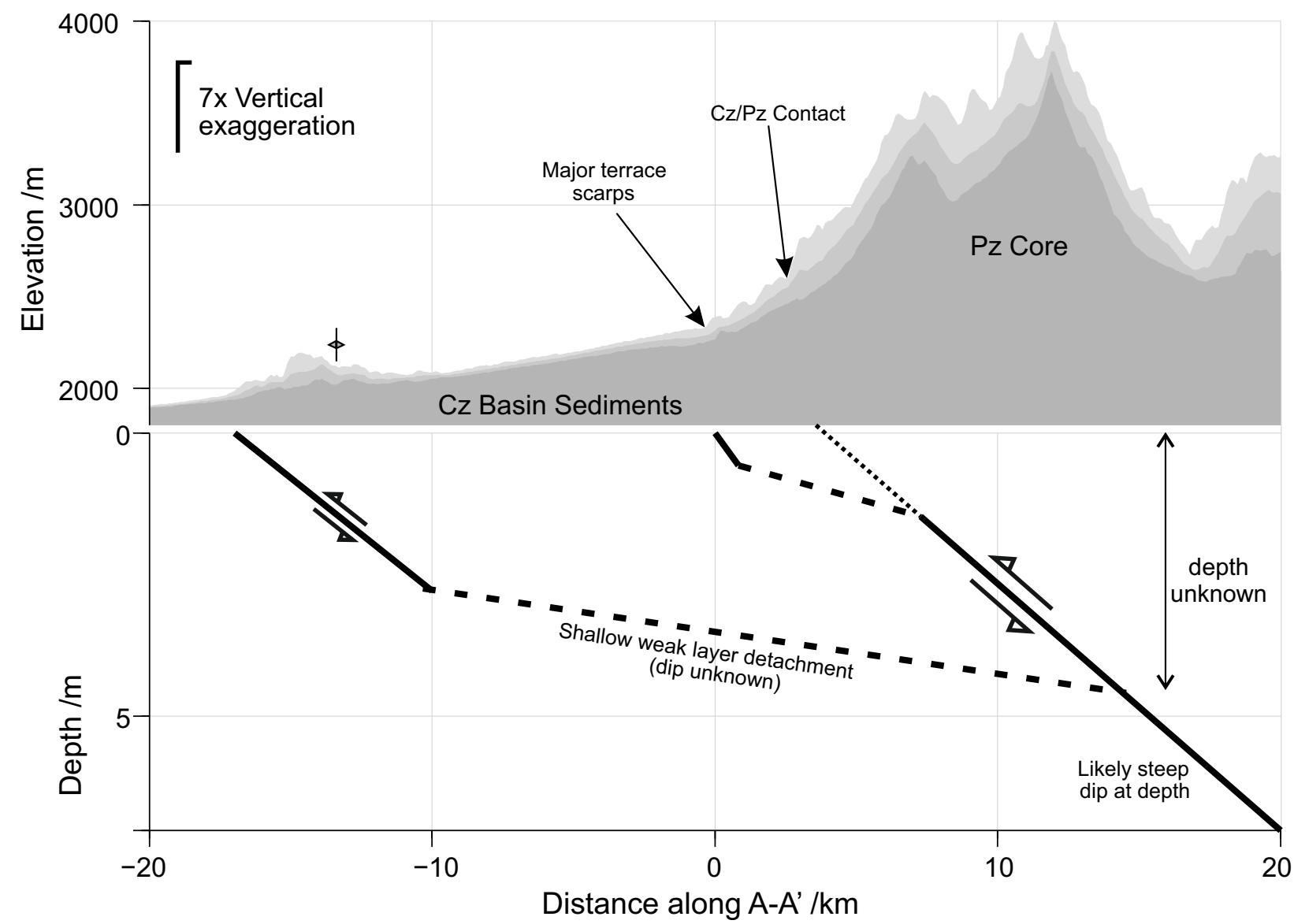

Figure 15. Conceptual model of the Karkara Rangefront Fault (KRF) and the Kegen Basin Fold $(\mathrm{KBF})$. The KBF has a width of $6.5 \mathrm{~km}$, suggesting that it is underlain by a ramp that shallows into a detachment at several kilometres depth, and which we interpret to extend southwards to connect with the KRF. The active trace of the KRF is sited north of the Cenozoic-Palaeozoic bedrock contact. The deformation of terraces in the hanging wall of the fault suggest that it shallows into a detachment at only 1-2 km depth, which is also likely to splay from the main fault zone. 


\begin{tabular}{|c|c|c|c|c|c|c|c|c|}
\hline $\mathbf{N}$ & $\begin{array}{l}\text { Lab } \\
\text { code }\end{array}$ & Rc & Material & Terrace & $\begin{array}{c}\text { Depth } \\
(\mathrm{cm})\end{array}$ & $\begin{array}{c}\text { Delta-13C } \\
(o / o o)\end{array}$ & $\begin{array}{c}\text { Conventional } \\
\text { Radiocarbon } \\
\text { Age (yr BP) } \\
\end{array}$ & $\begin{array}{c}\text { Calibrated } \\
\text { Age } \\
(y r B P) \\
\end{array}$ \\
\hline $\mathrm{C} 1$ & 397882 & Rc3 & Organic rich sediment & II & 86 & -19.3 & $4280 \pm 30$ & $4.82-4.96$ \\
\hline $\mathrm{C} 2$ & 395357 & Rc3 & Organic rich sediment & II & 105 & -10.7 & $22850 \pm 90$ & $26.99-27.45$ \\
\hline $\mathrm{C} 3$ & 397881 & $\mathrm{Rc} 1$ & Bulk organic rich soil & I & $35-41$ & -23.9 & $3750 \pm 30$ & $3.99-4.23$ \\
\hline $\mathrm{C} 4$ & 395371 & Rc1 & Peat/Soil clast & I & 58 & -20.8 & $8710 \pm 30$ & $9.55-9.76$ \\
\hline C5 & 397880 & Rc1 & Peat/Soil clast & II & 124 & -20.4 & $12440 \pm 50$ & $14.22-14.94$ \\
\hline C6 & 395348 & Rc1 & Peat/Soil clast & III & 76 & -20.7 & $24400 \pm 100$ & $28.2-28.7$ \\
\hline $\mathrm{C} 7$ & 395350 & Rc1 & Peat/Soil clast & III & 88 & -21.7 & $9340 \pm 30$ & $10.44-10.66$ \\
\hline $\mathrm{C} 8$ & 397883 & Rc1 & Bulk organic rich soil & IV & 67 & -21.8 & $8050 \pm 30$ & $8.78-9.03$ \\
\hline C9 & 404173 & Rc1 & Bulk clay & IV & 80 & -22.8 & $10860 \pm 40$ & $12.69-12.80$ \\
\hline $\mathrm{C} 10$ & $35584^{*}$ & Q7 & $\begin{array}{l}\text { Amalgamated gastropod } \\
\text { shell fragments }\end{array}$ & - & 150 & -6.3 & $32230 \pm 190$ & $35.7-36.5$ \\
\hline $\mathrm{C} 11$ & $35585^{*}$ & Q7 & $\begin{array}{l}\text { Amalgamated gastropod } \\
\text { shell fragments }\end{array}$ & - & 160 & -8.6 & $34110 \pm 210$ & $38.2-39.1$ \\
\hline
\end{tabular}

Table 1. Full description of the Radiocarbon ages obtained at each of the sites studied along the Karkara Rangefront. Rc1-3: Karkara Rangefront, Q7: Kegen Basin Fold. Ages are reported as radiocarbon years before present where present $=$ AD 1950. Sample analysis was performed by Beta Analytics except for those marked * which were analysed at the Oxford Radiocarbon Accelerator Unit (ORAU). Ages calibrated based on the IntCal13 atmospheric curve (Reimer 2013), using the OxCal utility (Bronk Ramsey 2009). Errors on the radiocarbon age are 1- $\sigma$ analytical uncertainties. The calibrated age range presented is the $95 \%$ confidence interval based on the analytical uncertainty and the uncertainty in the calibration curve. 


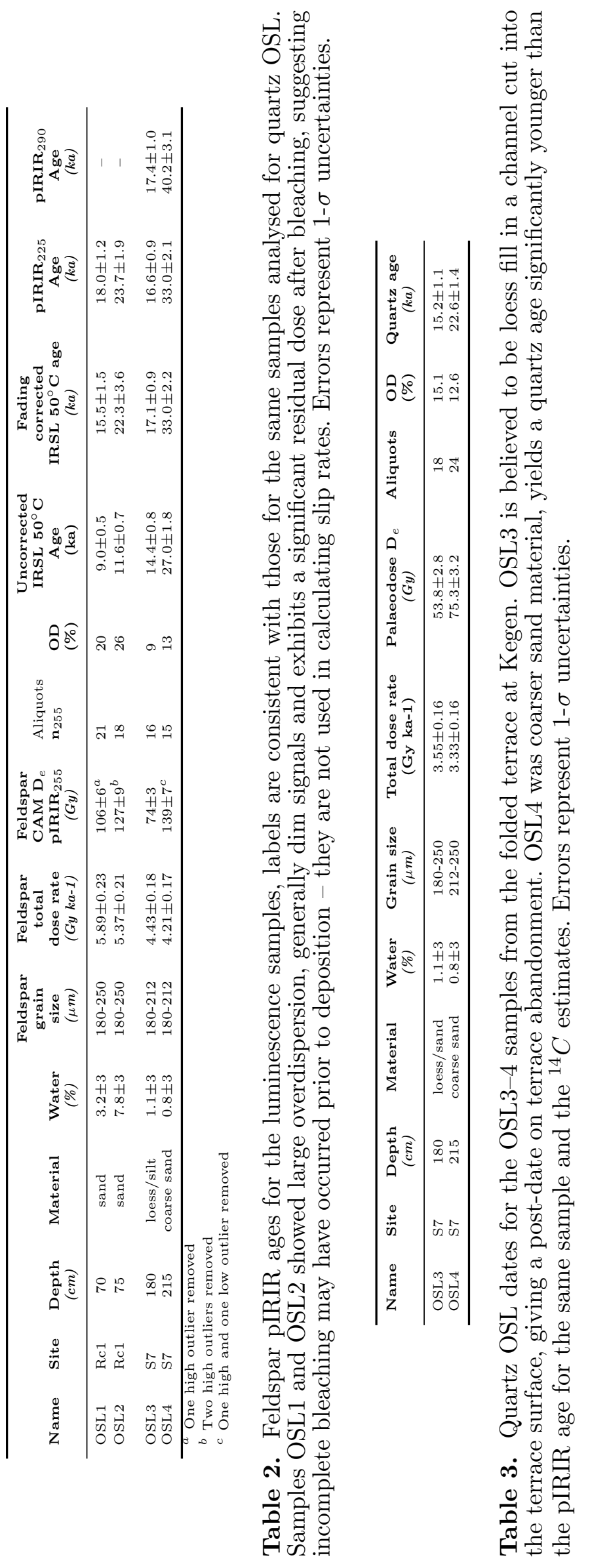


${ }_{889}$ This paper has been produced using the Blackwell Scientific Publications GJI LATEX2e class file. 